\title{
Fine sediment transport into the hyper-turbid lower Ems River: the role of channel deepening and sediment-induced drag reduction
}

\author{
Dirk S. van Maren • Johan C. Winterwerp • Julia Vroom
}

Received: 30 May 2014 / Accepted: 19 February 2015 /Published online: 13 March 2015

(C) The Author(s) 2015. This article is published with open access at Springerlink.com

\begin{abstract}
Deepening of estuarine tidal channels often leads to tidal amplification and increasing fine sediment import. Increasing fine sediment import, in turn, may lower the hydraulic drag (due to a smoother muddy bed and/or sedimentinduced damping of turbulence), and therefore, further strengthen tidal amplification, setting in motion a process in which the sediment concentration progressively increases until the river becomes hyper-turbid (Winterwerp and Wang, Ocean Dyn 63(11-12):1279-1292, 2013). To advance our understanding of the relative role of bed roughness and bed topography on sediment import mechanisms and sediment concentration, a Delft3D numerical model has been setup for an estuary which has been deepened and as a consequence experienced a strong increase in suspended sediment concentration: the lower Ems River. This model is calibrated against present-day hydrodynamic and sedimentary observations, and reproduces the basic sediment transport dynamics despite simplified sedimentological formulations. Historic model scenarios are semi-quantitatively calibrated against historic high and low water observations, revealing that changes in hydraulic roughness and deepening are probably equally important for the observed tidal amplification. This model is subsequently used to better understand historic changes in the hydrodynam-
\end{abstract}

Responsible Editor: Courtney Harris

This article is part of the Topical Collection on the 12th International Conference on Cohesive Sediment Transport in Gainesville, Florida, USA, 21-24 October 2013

D. S. van Maren $(\varangle) \cdot$ J. C. Winterwerp $\cdot$ J. Vroom

Coastal and Marine Systems, Deltares,

PO Box 177, 2600 MH Delft, The Netherlands

e-mail: bas.vanmaren@deltares.nl

J. C. Winterwerp

Environmental Fluid Mechanics, Delft University of Technology,

PO Box 5048, 2600 GA Delft, The Netherlands ic and sediment transport processes in the lower Ems River. Import of fine sediment has increased because of larger tidal transport, even though the degree of tidal asymmetry may not have significantly changed. The resulting rise in suspended sediment concentration reduced hydraulic drag, amplifying the tidal range. Export of fine sediment became less because the river-induced residual flow velocity decreased with deepening of the channel.

Keywords Tidal amplification · Tidal asymmetry $\cdot$ Hydraulic drag · Bed roughness $\cdot$ Hyper-turbid $\cdot$ Human impacts · Channel deepening $\cdot$ Lower Ems River

\section{Introduction}

Many estuaries worldwide, but particularly in Western Europe, have been deepened in the past decades to centuries, allowing ship access to inland ports. Both deepening and reclamation of intertidal areas have led to an increasing tidal range, with tides penetrating increasingly deeper up-estuary (Winterwerp and Wang 2013; Winterwerp et al. 2013). Some examples include the Ems River (Winterwerp et al. 2013; de Jonge et al. 2014), the Elbe (Kerner 2007; Winterwerp et al. 2013), the Weser (Schrottke et al. 2006) and the Loire (Walther et al. 2012; Winterwerp et al. 2013). In some (possibly all), the turbidity of these rivers also increased significantly, in line with the relation between tidal range and turbidity levels documented by Uncles et al. (2002). Winterwerp and Wang (2013) identified a feedback mechanism between tidal deformation (notably resulting from channel deepening and reclamation of intertidal areas), fine sediment import (leading to increasing suspended sediment concentrations) and effective hydraulic drag (decreasing as a 
result of increasing suspended sediment concentrations) which in turn strengthens tidal deformation-see Fig. 1. Because of this positive feedback mechanism, deepening or other engineering interventions may set into motion an evolution in which the tides become progressively more asymmetric, continuously more sediment is imported and the hydraulic drag becomes increasingly lower. The tidal evolution of five European rivers were recently investigated by Winterwerp and Wang (2013) and Winterwerp et al. (2013), using an analytical model to analyse historical data in which this feedback mechanism is accounted for. This study aims to investigate this feedback in a heavily engineered estuary, the lower Ems River, using a numerical model.

The lower Ems River is a 60 -km-long tidal river draining into the Ems estuary close to the border between Germany and the Netherlands. The (non-tidal) Ems River transports very little sediment: the majority of sediment in the lower Ems River and the Ems Estuary originates from the adjacent seas (the Wadden Sea and North Sea). The present-day lower Ems River is characterized by thick and mobile fluid mud with concentrations up to $200 \mathrm{~kg} / \mathrm{m}^{3}$ (Papenmeier et al. 2013) which migrates up- and down-estuary with the tide over a distance of about $10 \mathrm{~km}$; at low river flow high sediment concentrations are measured up to Herbrum, where a weir in the river has been constructed (Talke et al. 2009). The suspended sediment concentration has been increasing for decades (de Jonge et al. 2014) and the river probably became hyper-turbid somewhere in the 1990s, but the exact timing of the fluid mud appearance is difficult to establish because of data limitations. The appearance of fluid mud was likely accompanied by a decreasing hydraulic drag in the river, inferred from an analysis of long-term water level observations with an analytical model (Winterwerp and Wang 2013; Winterwerp et al. 2013). Recent semi-analytical model studies related the up-estuary shift of the Estuarine Turbidity Maximum (ETM), resulting from channel deepening, to changes in tidal asymmetry (Chernetsky et al. 2010) and bed roughness (de Jonge et al. 2014). Unfortunately, such semi-analytical models lack the bathymetric complexities, more realistic hydrodynamics and non-linear sediment transport processes. These non-linear processes are represented in processbased numerical sediment transport models. When reproducing present-day and historic observations of hydrodynamics and sediment concentrations, such numerical models provide powerful tools to quantitatively analyse changes in sediment transport mechanisms. Our aim is, therefore, to gain further quantitative insight in the relation between deepening, tidal dynamics, suspended sediment concentration and hydraulic drag using a well-calibrated numerical sediment transport model.

\section{Historic development of the lower Ems River}

The lower Ems River and Ems estuary, situated around the Dutch-German border (Fig. 2), have undergone large maninduced changes in the past decades to centuries. Land reclamations carried out in the past 500 years have greatly reduced the intertidal area, and human interferences have even accelerated in the past 50 years. Three ports and a large shipyard exist along the estuary, requiring regular deepening and permanent maintenance dredging of the access channel. The tidal channels in the Ems Estuary used to be characterized by distinct ebb- and flood channels (van Veen 1950). Some of these channels have degenerated, effectively transforming parts of the estuary into a single-channel system. However, the impact of human activities is most pronounced in the lower Ems River.

The lower Ems River was deepened from a water depth of $\sim 4 \mathrm{~m}$ below HW to $\sim 8 \mathrm{~m}$ below HW between the 1930s and 1994 - see Table 1 for details. This deepening has led to strong tidal amplification (see Fig. 3), possibly amplified by the presence of the weir at Herbrum constructed in 1899 (Schuttelaars et al. 2013). The tidal range at Papenburg (km 0) has increased from $1.6 \mathrm{~m}$ in 1950 to $3.6 \mathrm{~m}$ in 2010, with a major lowering of the tidal low water level (Krebs and Weilbeer 2008). Until 1990, the tidal range peaked at Emden (42 km seaward of Papenburg), because the tide was damped further in the up-estuary direction. Since then, the tide is
Fig. 1 Estuarine response to channel deepening, in which tidal dynamics initially respond to the geometrical changes, and set in motion a positive feedback mechanism in which increasing fine sediment import and resulting decrease in hydraulic drag lead to a progressively larger tidal deformation

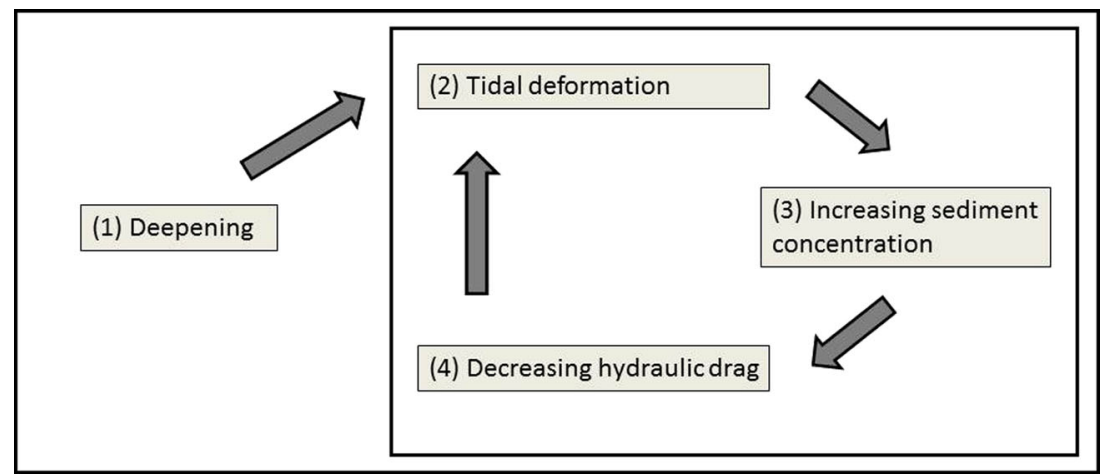



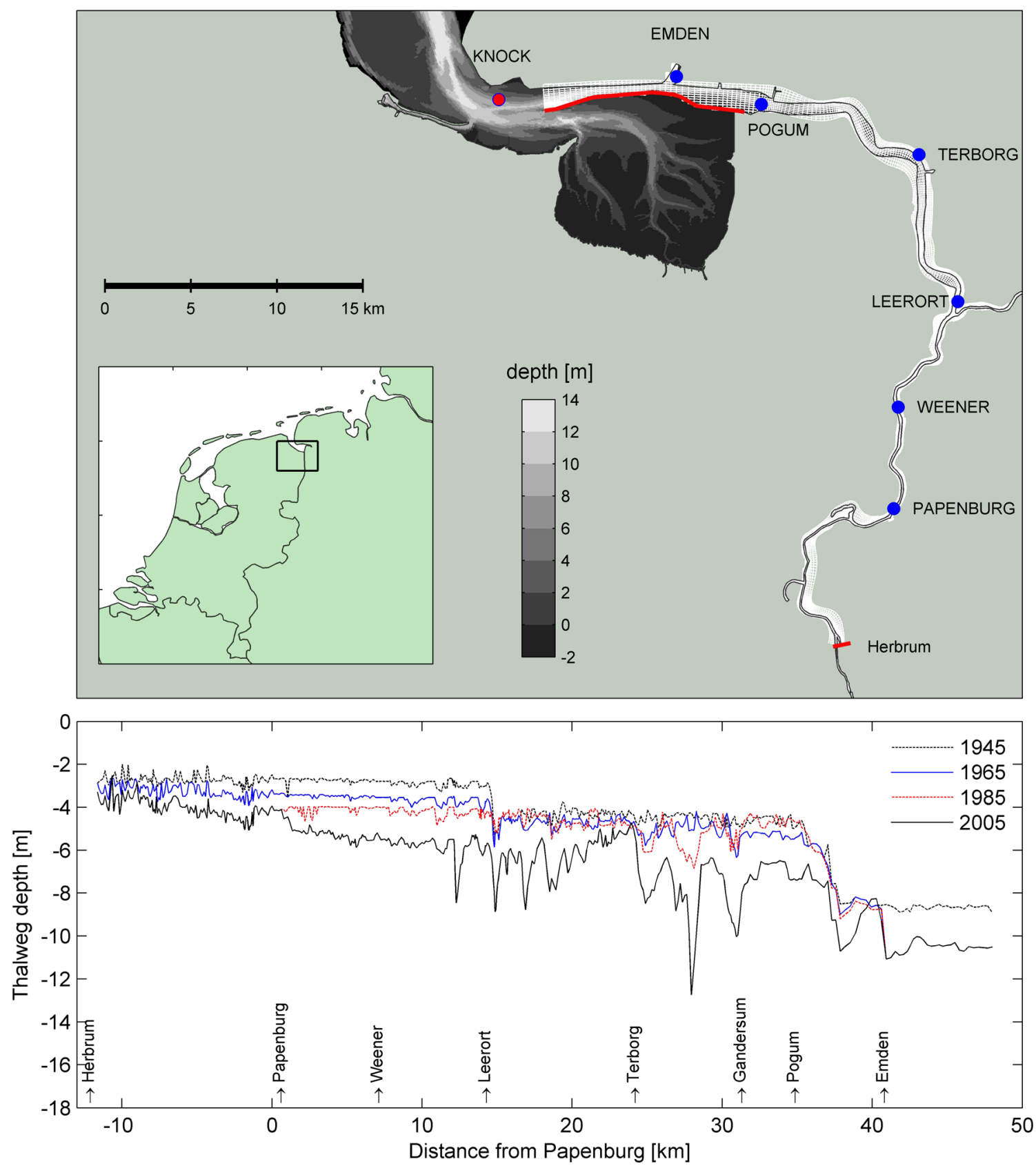

Fig. 2 Map of the lower Ems River (from the weir at Herbrum to Emden), the Emden navigation channel (between Emden and Knock), and part of the Ems Estuary. The depth is in meter below MSL. The Emden navigation channel is separated from the Ems estuary by a dam (thick red line). The model (numerical grid in white) covers the lower Ems River and the confined section of the Emden navigation channel. The water level and sediment concentration observation stations are

amplified upstream of Emden, and within 20 years the tidal range at Papenburg has become $50 \%$ larger than the tidal range at Emden. Deepening also led to a more pronounced flood-dominated tidal asymmetry (Herrling and Niemeyer 2008; Chernetsky et al. 2010) and possibly density-driven flow (Talke et al. 2009; Donker and de Swart 2013). The increasing flood-dominated asymmetry strengthened various denoted with blue dots, and the red dot marks the location of velocity data and seaward model boundary conditions (Knock). The upstream model boundary is the weir at Herbrum (red line). The lower panel provides the observed bathymetry along the thalweg of the lower Ems River (2005) and reconstructed depth (1945-1985; see text for explanation). The bed level has not changed in the navigation channel since 1965 (red overlaps black and blue lines)

sediment importing mechanisms related to resuspension, vertical mixing and flocculation (Winterwerp 2011) and lag effects (Chernetsky et al. 2010). The present-day lower Ems River is characterized by thick, soft mud deposits with concentrations up to $500 \mathrm{~kg} / \mathrm{m}^{3}$, which probably remain mobile at concentrations below $\sim 200 \mathrm{~kg} / \mathrm{m}^{3}$ (Papenmeier et al. 2013). 
Table 1 Chronology of channel deepening and other interventions in the lower Ems River, from Schoemans (2013), based on Herrling and Niemeyer 2008; Krebs and Weilbeer 2008, and pers. comm. Krebs (2013)

\begin{tabular}{|c|c|c|c|c|c|}
\hline \multirow[t]{2}{*}{ Year } & \multirow[t]{2}{*}{ Intervention } & \multicolumn{4}{|c|}{ Historic scenario } \\
\hline & & 1945 & 1965 & 1985 & 2005 \\
\hline Before 1939 & Emden fairway below $-6 \mathrm{~m} \mathrm{CD}$ & & & & \\
\hline $1932-1939$ & Pogum-Leerort $5.5 \mathrm{~m}$ below MHW, Leerort-Papenburg $4.2 \mathrm{~m}$ below MHW & & & & \\
\hline $1939-1942$ & Emden fairway at $-7 \mathrm{~m} \mathrm{CD}$ & & & & \\
\hline $1942-1948$ & No maintenance dredging: Emden fairway at $-5.8 \mathrm{~m} \mathrm{CD}$ & & & & \\
\hline 1957 & Emden fairway at $-8 \mathrm{~m} \mathrm{CD}$ & & & & \\
\hline $1961-1962$ & Leerort-Papenburg $5 \mathrm{~m}$ below MHW. & & & & \\
\hline 1965 & Emden fairway at $-8.5 \mathrm{~m} \mathrm{CD}$ & & & & \\
\hline $1983-1986$ & Emden-Papenburg $5.7 \mathrm{~m}$ below MHW & & & & \\
\hline 1984-1985 & Straightening of bends, reducing the river length with $1 \mathrm{~km}$. & & & & \\
\hline 1991-1994 & Emden-Papenburg $7.3 \mathrm{~m}$ below MHW & & & & \\
\hline $2001-2002$ & Construction of storm surge barrier (near Pogum) & & & & \\
\hline
\end{tabular}

$M H W$ mean high water, $C D$ chart datum

\section{Numerical model setup}

In order to explain quantitatively the changing tidal dynamics and sediment importing mechanisms, a hydrodynamic and morphodynamic model is applied. The sediment transport processes in the Ems estuary are very complex, and models representing all relevant physical processes probably do not exist. Our aim is to obtain a quantitative understanding of the changes in sediment transport mechanisms in the estuary. Therefore, the model should reproduce the main characteristics of the estuary, using available data on tidal dynamics (water levels and flow velocity), salinity, sediment concentration, and residual fluxes. Subsequently, historic model scenarios are evaluated, aiming at reproducing estimated historic high and low water levels. These scenarios are then analysed for changes in transport mechanisms.

\subsection{Hydrodynamics}

A 3D hydrodynamic model has been setup in the Delft3D model system (see Lesser et al. 2004) for the year 2005; a year for which a large amount of hydrodynamic, bathymetric and sedimentary data is available. The model domain covers the river from the weir at Herbrum to several $\mathrm{km}$ eastward from Knock, i.e. a length of $65 \mathrm{~km}$. In the last $\sim 10 \mathrm{~km}$ of the model domain, the river is separated from the Ems estuary (Fig. 2) by a training wall. The width of the channel increases from $\sim 70 \mathrm{~m}$ (Herbrum) to $120 \mathrm{~m}$ at Papenburg, and over $500 \mathrm{~m}$ at Pogum. The curvilinear grid contains a total of 7,035 active cells in the horizontal $(x-y)$ dimension and 10 equidistant vertical $\sigma$ layers. The average grid cell size is 50 (cross-channel) by 100 (along-channel) meters, and down to $20 \mathrm{~m}$ in the narrow upstream reaches of the river. The model is forced at the

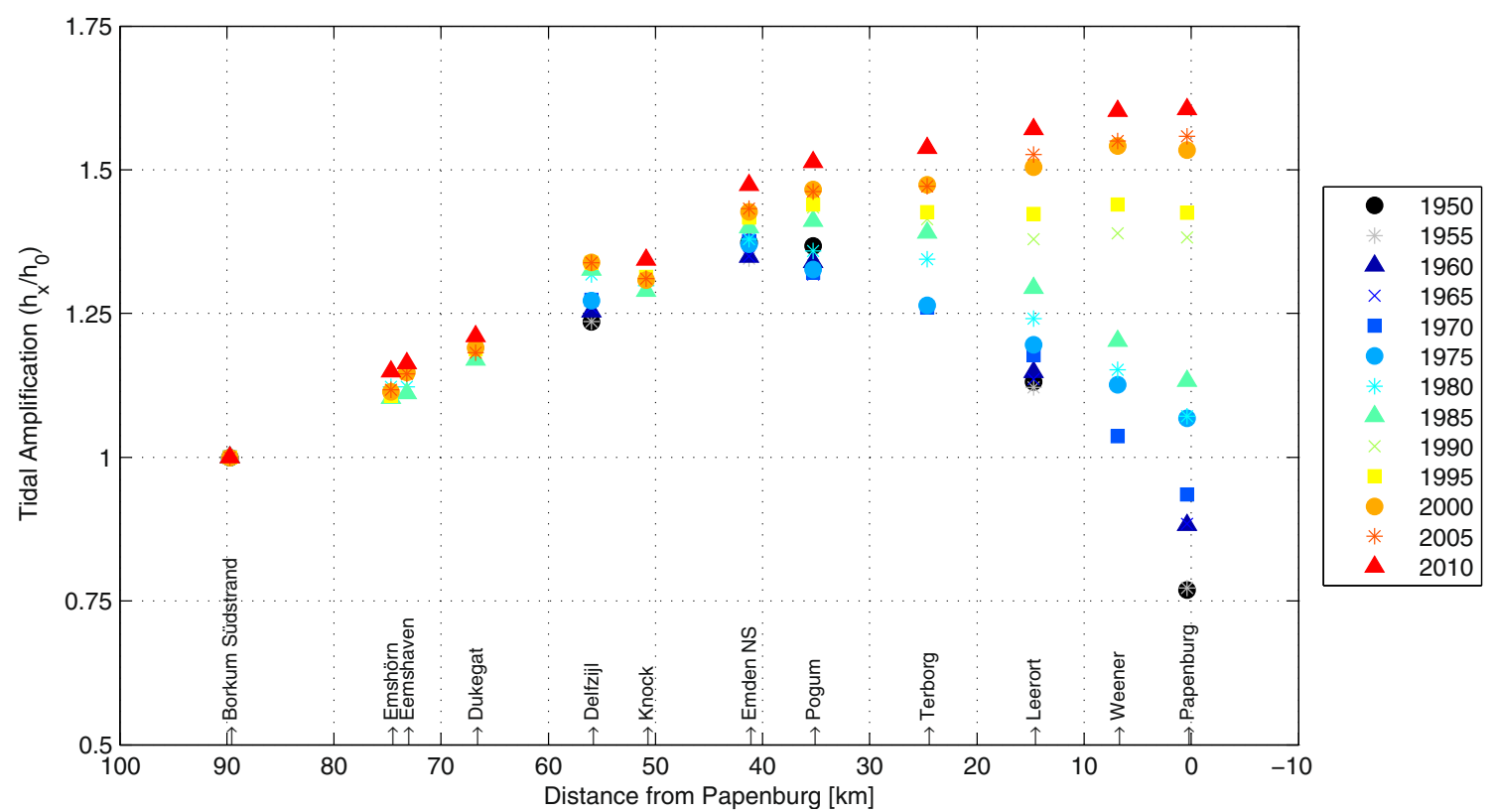

Fig. 3 Observed tidal amplification $h_{x} / h_{0}$ in the Ems estuary and lower Ems River, defined as the tidal range $h_{x}$ relative to the tidal range at the most seaward station (Borkum Südstrand; $h_{0}$ ), from Borkum Südstrand
(Ems - km 89) to Papenburg (Ems—-km 0). The entrance of the lower Ems River is close to Knock 
seaward open boundary by water levels and salinity observed at the gauging station Knock, and at the landward boundary by discharges at the weir Herbrum (measured further upstream at Verssen) and at Leer (the Leda River joins the Ems River at Leerort, see Fig. 2). The combined total fresh water discharge typically varies between 30 and $250 \mathrm{~m}^{3} / \mathrm{s}, 80 \%$ of which is through Herbrum. Vertical mixing is computed with the standard $\mathrm{k}-\varepsilon$ turbulence model, and the bed roughness is varied and modeled with a Manning's $n$ coefficient. The Manning's $n$ relates to the Chézy bed friction coefficient $C$ (in $\mathrm{m}^{1 / 2} / \mathrm{s}$ ) and water depth $h$ as $n=h^{\frac{1}{6}} / C$ (Chow 1959). For a given $n$ value, the Chézy coefficient therefore increases with water depth. Although the unit of the Manning's coefficient is $\mathrm{s} / \mathrm{m}^{-1 / 3}$, it is used so frequently throughout this paper that the unit is hereafter omitted.

The model is calibrated against water levels observed at six stations along the estuary by varying the bed roughness. The present-day lower Ems River is hydraulically smooth because of the large amount of fluid mud in the system, which is accounted for by the bed roughness. For each station, the computed and observed water levels are decomposed into amplitudes and phases of the main harmonic constituents (using T-Tide, Pawlowicz et al. 2002). Using a low hydraulic roughness (Manning's $n=0.01$, typically for muddy, hydraulically smooth beds), the amplitude of all major tidal constituents is well reproduced - only $\mathrm{M}_{4}$ is overestimated by about $10 \%$ (see the upstream station Papenburg in Fig. 4). The phase difference of the main shallow water constituents $\left(\mathrm{M}_{4}\right.$, $\mathrm{M}_{6}$ and $\mathrm{MS}_{6}$ ) is overestimated by $10-30^{\circ}$. The main constituent, $\mathrm{M}_{2}$, is slightly overestimated in the middle part of the estuary (see the along-estuary distribution of $\mathrm{M}_{2}$ in Fig. 5). A likely cause for this model shortcoming is that in reality the presence and properties of fluid mud are varying along the estuary, whereas the model assumes a constant roughness value. Using larger Manning's $n$ values ( 0.015 to 0.02 , typical for sand), the tides are much more damped, reducing the $\mathrm{M}_{2}$ amplitude at Papenburg with $0.5 \mathrm{~m}$. This implies that a large fraction of the tidal amplification in the lower Ems River is caused by a decrease in hydraulic roughness, as suggested before by Winterwerp et al. (2013) - this important observation will be quantified in more detail in this paper.

Flow velocities have been measured several $\mathrm{km}$ seaward of the model domain (near Knock, see Fig. 2 for location). Here, the Ems River is no longer confined by a training wall, and therefore, the computed velocity cannot be directly compared with the observed velocity. However, the observation station is sufficiently close to the model domain to qualitatively compare observed and computed flow velocities (Fig. 6) and to interpret the modeled tidal dynamics later in this paper. The intra-tidal flow velocity distribution corresponds with observations, with a rapid increase in flow velocities at the beginning of flood, and a more symmetric distribution of the flow velocity over the ebb period. Especially the ebb flow is sensitive to the prescribed Manning's $n$, with larger flow velocities with increasing $n$. The computed ebb-dominant flow velocity must be affected by a local effect though, demonstrated by the larger computed discharge peaks during the flood.

\subsection{Sediment transport}

\subsubsection{Model formulations}

The sediment dynamics in the lower Ems River are complex, mainly due to the existence of mobile fluid mud layers with concentrations up to $200 \mathrm{~kg} / \mathrm{m}^{3}$ (Papenmeier et al. 2013) which may be flushed down-estuary during events but migrate back up-estuary during tidally dominated conditions (Wang 2010). These layers cannot be accurately modelled on time and spatial scales of interest to this study. The processes relevant for consolidation and entrainment require a very large
Fig. 4 Computed (black) and observed (red) harmonic water level amplitudes (top panel) and phases (lower panel) for 2005, as well as differences between observations and model results (gray bars) computed for a full year of observations and model results at Papenburg for

Manning's $n=0.01$

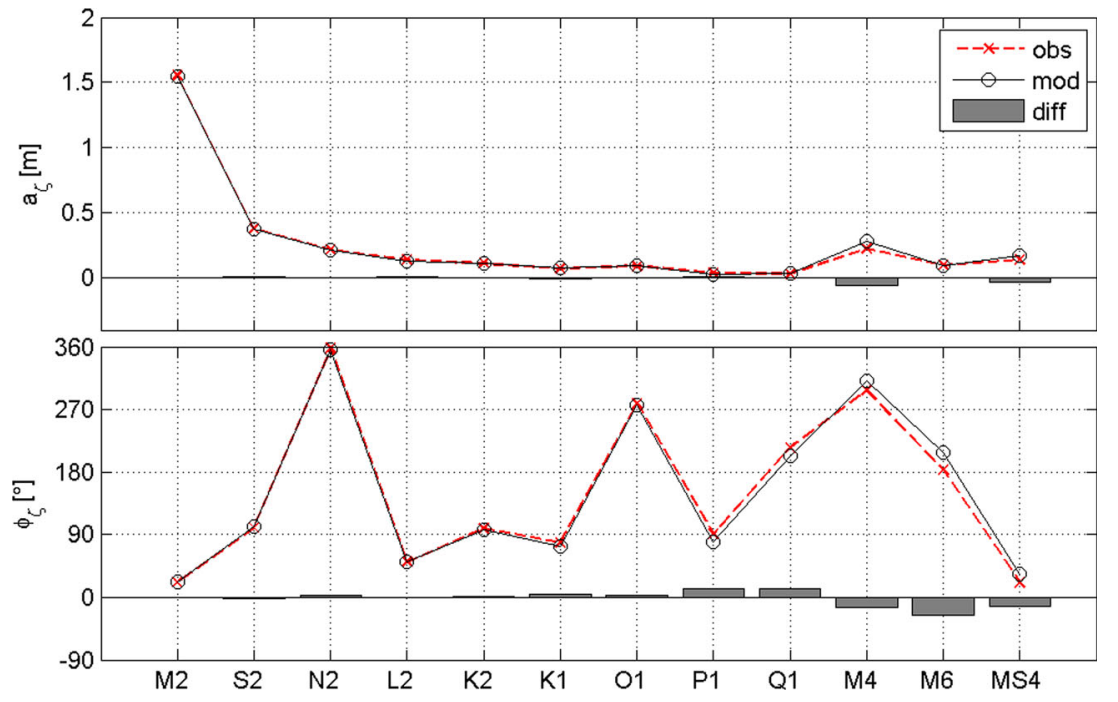


Fig. 5 Observed water level phase $\phi_{\zeta}$ (upper panel) and amplitude $a_{\zeta}$ (top panel) of $\mathrm{M}_{2}$ (black dots) and $\mathrm{M}_{4}$ (grey diamonds) throughout the lower Ems River, and modeled $\mathrm{M}_{2}$ (solid lines) and $\mathrm{M}_{4}$ (dashed lines) phase (top panel) and amplitude (lower panel) using a Manning coefficient of 0.01 (blue), 0.015 (red), and 0.02 (black), all for 2005

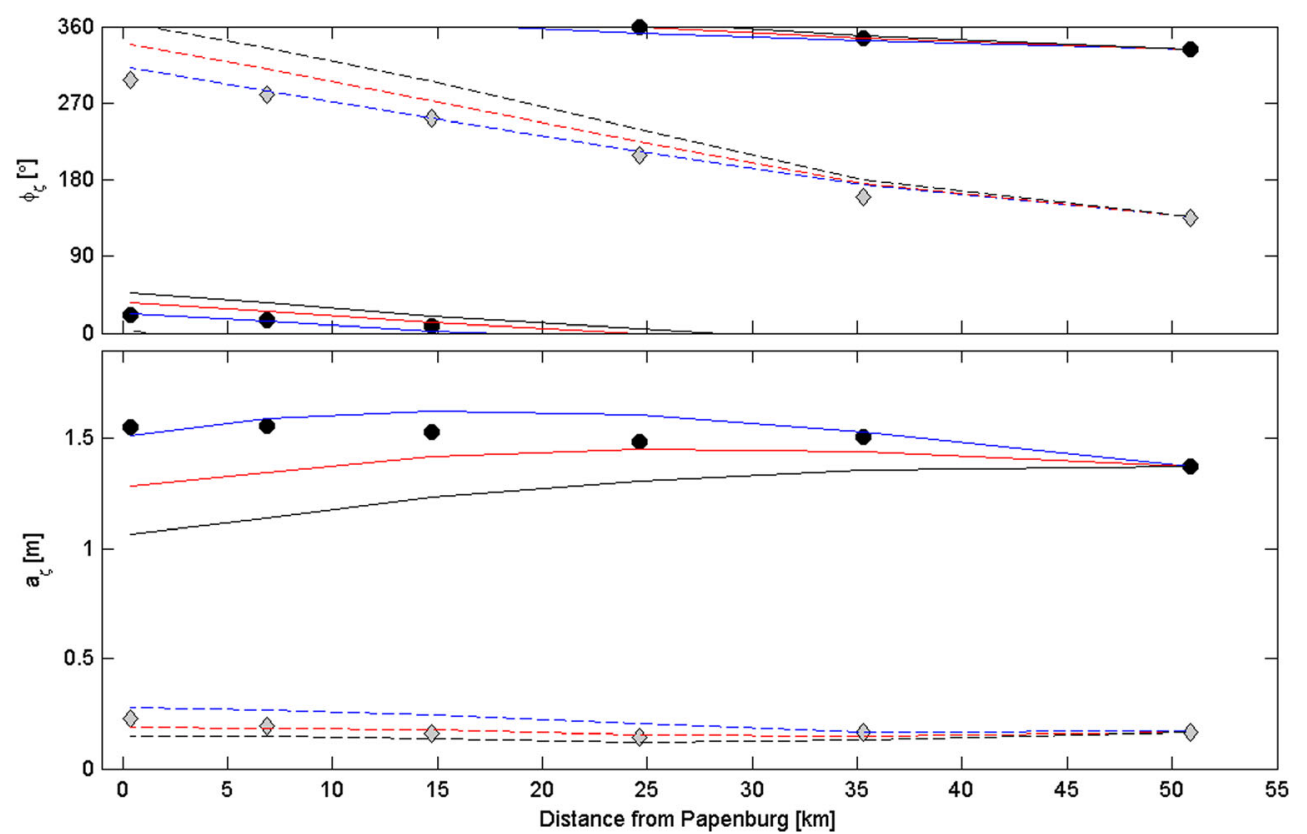

vertical resolution, and hence, computational time. Moreover, the governing physical processes are still insufficiently understood. As an alternative, we simulate the fluid mud in Delft3D as a dynamic single bed layer.

The upper part of the fluid mud layer in the lower Ems River is very soft. It has a vertically fairly uniform sediment concentration of $\sim 100$ to $200 \mathrm{~kg} / \mathrm{m}^{3}$, in which the viscosity remains relatively low (Papenmeier et al. 2013). This upper layer, with a thickness of typically $1-2 \mathrm{~m}$, is probably resuspended every tidal cycle (e.g. Talke et al. 2009; Wang 2010; Papenmeier et al. 2013). Hence, the erosion rate of the fluid mud layer is probably large, with a fairly low critical bed shear stress $\tau_{c r}$ and large erosion parameter $M$. We use a classical approach to describe the dynamics of the fluid mud layer: erosion is computed with Partheniades' equation for erosion $E$, and deposition $D$ as a shear stress independent flux (Sanford and Halka 1993; Winterwerp 2007):

$$
E=M\left(\frac{\tau}{\tau_{c r}}-1\right)
$$

$$
D=w_{s} c
$$

Herein $M$ is the erosion parameter $\left(\mathrm{kg} / \mathrm{m}^{2} / \mathrm{s}\right), \tau$ is the bed shear stress, $\tau_{c r}$ is the critical bed shear stress for erosion, $w_{s}$ is
Fig. 6 Water level (top), flow velocity (middle), and total discharge (lower panel). The water level is measured at Knock (see Fig. 2 for location) and imposed on the seaward boundary of the model. The flow velocity and discharge are computed at the seaward model boundary during spring tide (25-28 April 2005) using a Manning coefficient of 0.01 (blue line), 0.015 (dashed red line), and 0.02 (dash-dotted gray line). The flow velocity was observed (black, $1.6 \mathrm{~m}$ below the water surface) at station Knock
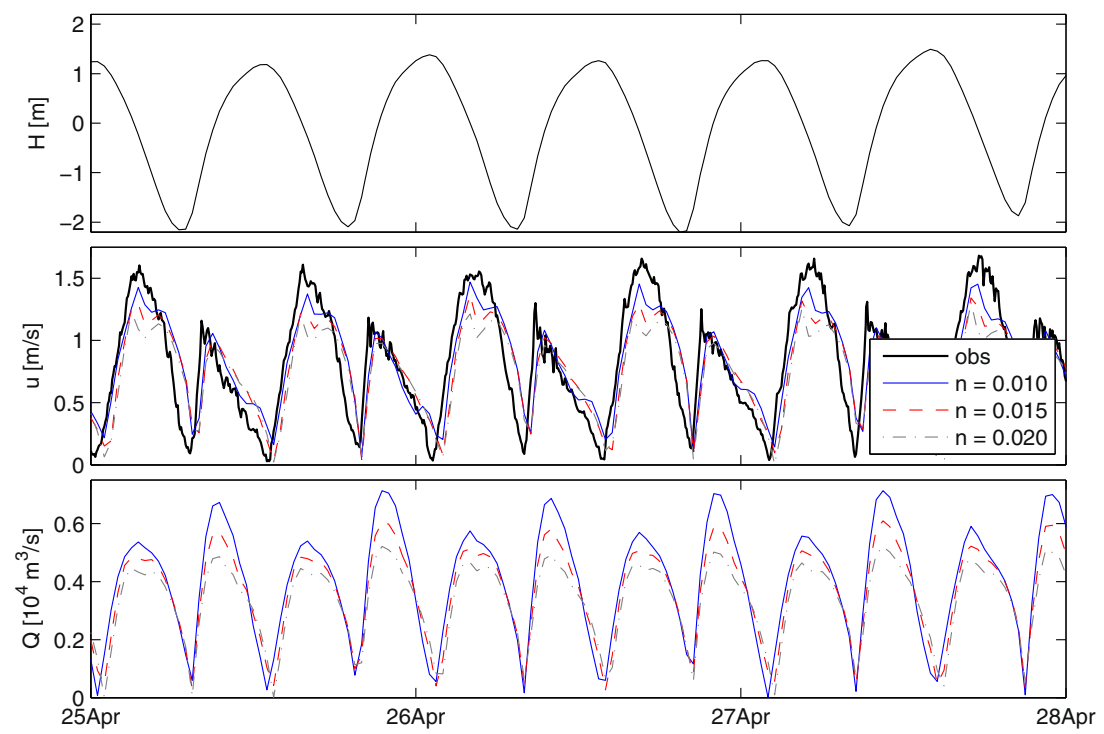
the settling velocity $(\mathrm{m} / \mathrm{s})$ and $c$ is the sediment concentration $\left(\mathrm{kg} / \mathrm{m}^{3}\right)$. The settling velocity is composed of a clear water settling velocity $w_{s 0}$, which is reduced by hindered settling effects using a simple power law equation based on Richardson and Zaki (1954):

$w_{s}=w_{s 0}\left(1-C / C_{\text {ref }}\right)^{5}$

Here $C_{\text {ref }}$ is the gelling concentration, at which a spacefilling network of sediment particles develops. A typical value of the gelling concentration for clay-dominated suspensions is $100 \mathrm{~kg} / \mathrm{m}^{3}$. In the lower Ems River, a turbid suspension up to several 10 's of $\mathrm{kg} / \mathrm{m}^{3}$ migrates up- and down-estuary with the tidal currents (Talke et al. 2009). Such values lead to substantially lower settling velocities: for $C_{\mathrm{ref}}=100 \mathrm{~kg} / \mathrm{m}^{3}$ and $C=$ $30 \mathrm{~kg} / \mathrm{m}^{3}$ the settling velocity is $83 \%$ lower. The equilibrium suspended sediment concentration increases with a decreasing settling velocity, and therefore, hindered settling leads to larger computed sediment concentrations. Furthermore, hindered settling leads to a smooth transition between the suspension and the fluid mud. The density of the mobile, low viscosity fluid mud is between 20 and $200 \mathrm{~kg} / \mathrm{m}^{3}$ (Papenmeier et al. 2013); we prescribe an average value of $100 \mathrm{~kg} / \mathrm{m}^{3}$ for the dry bed density $\rho_{\text {dry }}$ in the morphodynamic bed module.

The high sediment concentrations observed in the lower Ems River strongly influence turbulence mixing and thereby influence the hydrodynamics and sediment dynamics (Winterwerp 2001). The interaction of sediment, turbulence and hydrodynamics is modelled by including the effect of sediment on water density through the equation of state, which subsequently reduces turbulence mixing through the k- $\varepsilon$ model.

Two sediment fractions are applied in the model, one settling at $1 \mathrm{~mm} / \mathrm{s}$ (representing flocculated sediment) and a second at $0.2 \mathrm{~mm} / \mathrm{s}$ (representing poorly flocculated sediment). These values are the typical maximum settling velocity and average settling velocity (respectively) observed by van Leussen and Cornelisse (1996). All other parameters are set equal for both fractions. The value for $\tau_{c r}(0.5 \mathrm{~Pa})$ represents weakly consolidated sediment which is attained during most tidal conditions (typically the peak bed shear stress is 1-2 Pa). The erosion parameter $M$ is derived through model calibration (not reported here) against the observed sediment concentrations, resulting in a relatively high value of $0.01 \mathrm{~kg} / \mathrm{m}^{2} / \mathrm{s}$.

Finally, the model is forced with suspended sediment concentrations (SSC) observed at station Knock, close to the seaward model boundary (the main source of sediment in the lower Ems River). The SSC at this station (not shown) typically varies between 0 and $1 \mathrm{~kg} / \mathrm{m}^{3}$. The model is initialized without sediment on the bed, and is run for 2 years in which the first year is the spin-up period and the second year is used for detailed analyses. The similarity in SSC in the first and second year (not shown) suggests that this spin-up period is sufficient.

\subsubsection{Model results}

The seasonal variation in SSC in the lower Ems River is primarily regulated by the river discharge. Upstream of Terborg, the observed sediment concentrations are highest during river baseflow conditions and lowest during peak discharges; downstream of Terborg this seasonality is reversed. The model reproduces this typical yearly variation although with smaller seasonal differences than the data suggest (see the "Historic scenarios" section). The seasonal variation in model accuracy is evaluated with the correlation coefficient $R$ and with a skill score introduced by Wilmott (1981):

$$
\text { Skill }=1-\frac{\sum_{i=1}^{N}\left|X_{i, \text { model }}-X_{i, o b s}\right|^{2}}{\sum_{i=1}^{N}\left(\left|X_{i, \text { model }}-\overline{X_{i, o b s}}\right|+\left|X_{i, o b s}-\overline{X_{i, o b s}}\right|\right)^{2}}
$$

When the modelled variable $X_{i, \text { model }}$ is in perfect agreement with observation $X_{i, o b s}$, Skill $=1$; in absence of any correlation Skill $=0$. The model skill is computed using a 14-day running mean using observations of suspended sediment concentration at Papenburg, Weener, Terborg and Pogum (Fig. 7). This comparison reveals that both model Skill and $R$ are typically $>0.6$. Very low values for short periods of time are caused by errors in the data. The model Skill and correlation coefficient $R$ are

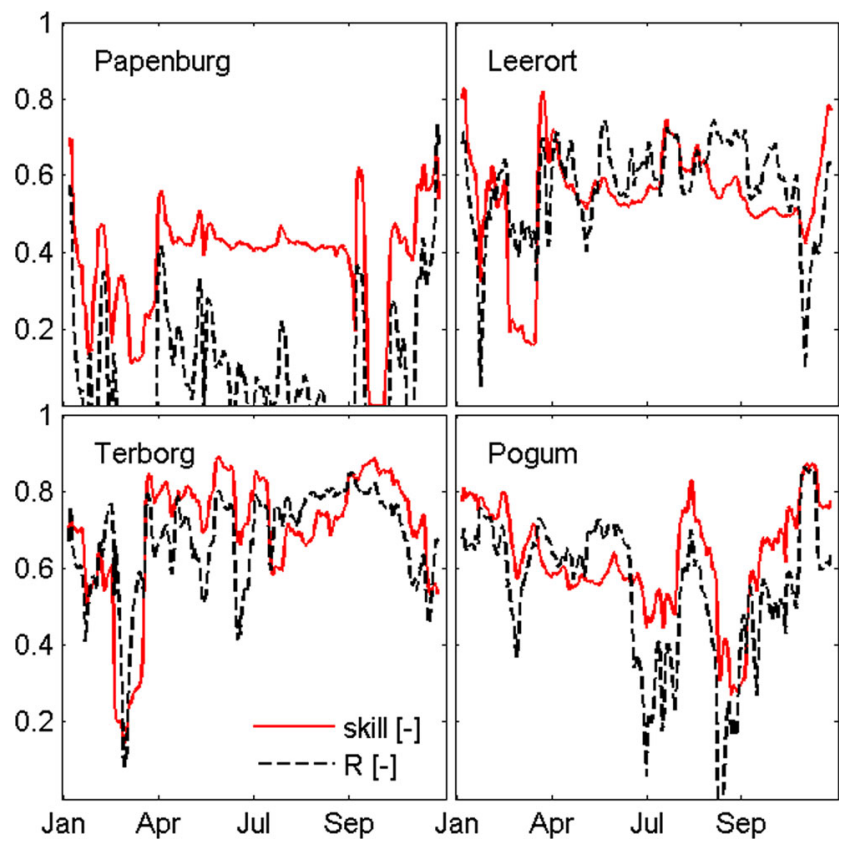

Fig. 7 Correlation coefficient $R$ (black) and model Skill (red), computed using a 14-day running mean for the near-bed suspended sediment concentration measured at Papenburg, Weener, Terborg, and Pogum 
poor for Papenburg, apparently the model fails to represent the correct physics here.

The spring-neap variation and intra-tidal variation in SSC are evaluated in more detail in December (a period of the year that the model performs well; see Fig. 7). The typical peaks in SSC are $5 \mathrm{~kg} / \mathrm{m}^{3}$ (neap tide) to $10 \mathrm{~kg} / \mathrm{m}^{3}$ (spring tide) at the two downstream stations Pogum and Terborg and about $2.5 \mathrm{~kg} / \mathrm{m}^{3}$ at stations Leerort and Papenburg (Fig. 8). The model reproduces these peak values in SSC at all stations, but at Pogum and Terborg the intra-tidal variation is better reproduced than at Leerort and Papenburg. It is not known why the intra-tidal variation at the latter two stations deviate more from observations; possibly the fluid mud dynamics are more complex. Since the two downstream stations are more representative for transport into and out of the estuary, we focus on their intra-tidal variation in SSC in more detail (Fig. 9).

At Pogum, both the observations and the model results display a double-crested peak sediment concentration around low water (LW). The first crest of this peak is during the end of $\mathrm{ebb}$ and the second is during the beginning of flood. These peaks are caused by tidal asymmetry, generating high ebb flow velocities which are followed rapidly by high flood flow velocities: sediment remains in suspension throughout LW. This will be elaborated in more detail in the "Sediment transport mechanisms" section. At Terborg, the modelled near-bed SSC crests have merged into a single peak during some spring tides, whereas observations still display a double-crested peak. Higher in the water column, the modelled concentration peaks are double-crested. Apparently, modelled sediment settles more slowly in the lower part of the water column around LW slack tide than the observations suggest.

With the model reproducing the typical SSC dynamics at the entrance of the lower Ems, it should also reproduce the net sediment fluxes. Typically, 1 million ton is annually dredged from the lower Ems River and brought on-land (Weilbeer and Uliczka 2012). In the first year of the simulation (without initial sediment on the bed or in suspension), 2 million ton
Fig. 8 Computed water level at Pogum (top panel), and observed (red line) and computed sediment concentration (blue lines) in December 2005 at Pogum (second panel), Terborg (third panel), Leerort (fourth panel), and Papenburg (bottom panel). The dark blue line is the average sediment concentration in the lower 10 to $30 \%$ of the water column, which best approximates the location of the sensor. The light blue lines depict the sediment concentration per layer, indicating the vertical variation in SSC. The sediment concentrations in the grey boxes are enlarged in Fig. 9
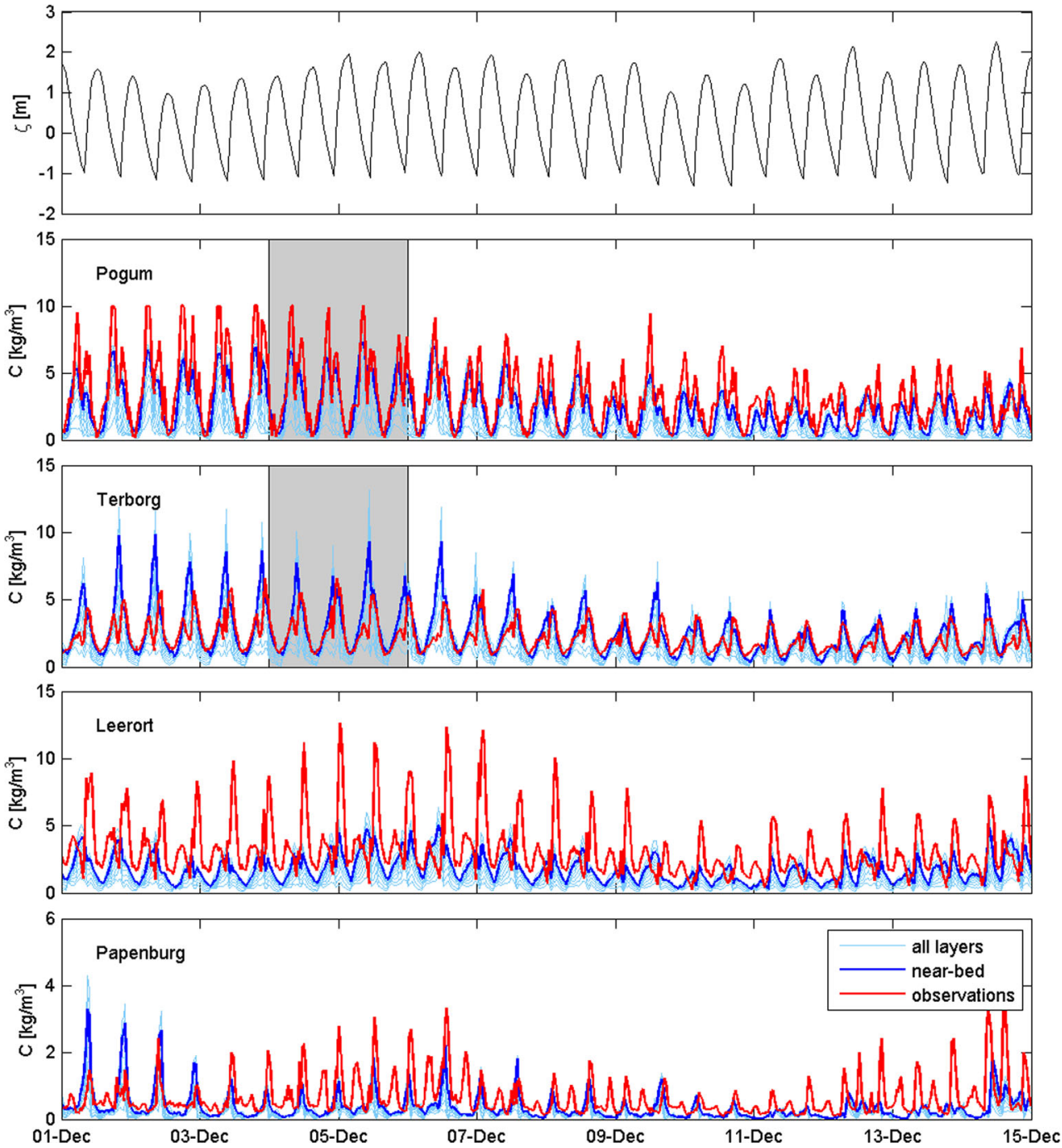
Fig. 9 Same as Fig. 8, but only for 4 and 5 December, and only for station Pogum (second panel) and Terborg (third panel)
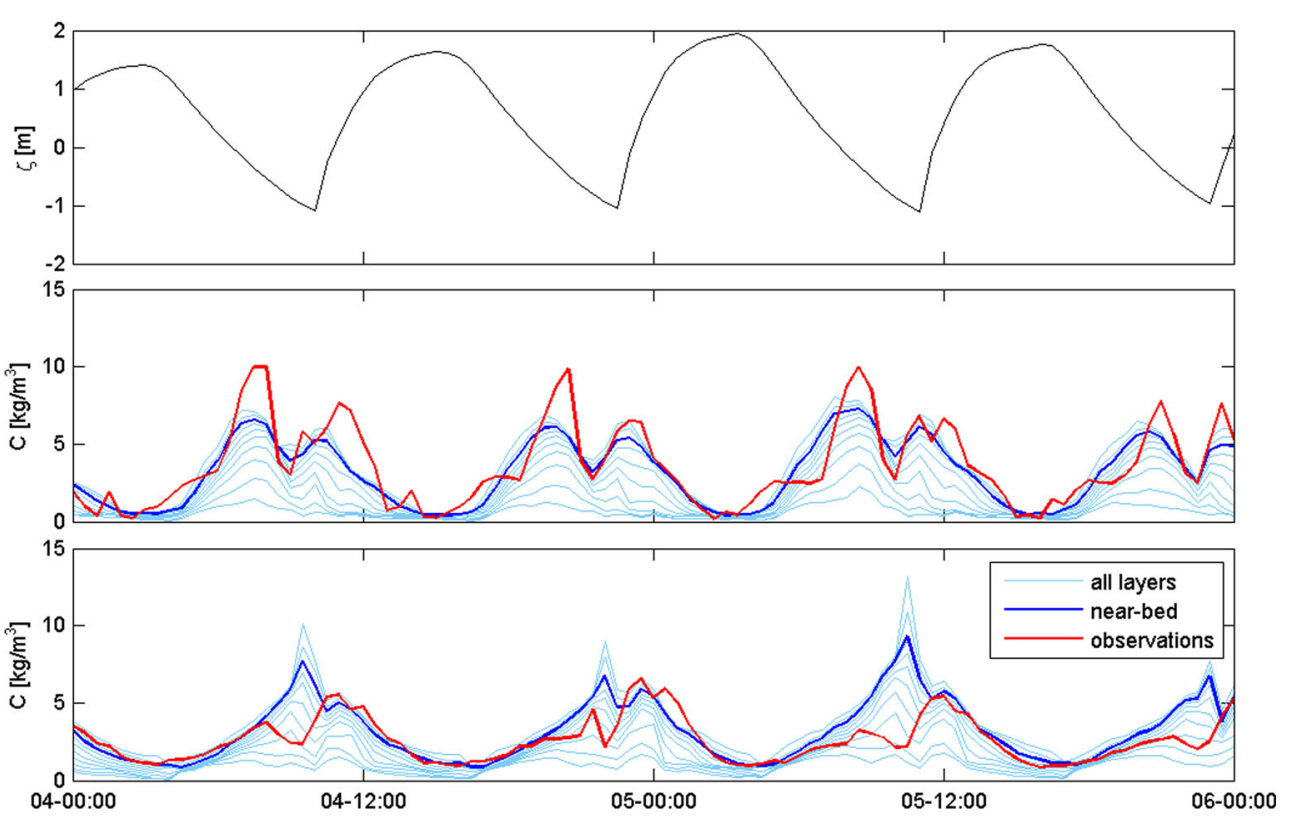

enters the lower Ems River. After the first simulation year, the import approaches zero because the model attains morphological equilibrium (and dredging is not included in the model). At morphological equilibrium, sediment import equals the amount of extracted sediment (as long as the import capacity exceeds extraction), which means that the model captures the large present-day up-estuary transport capacity. In the next section, historic scenarios are set-up to analyse changes in this up-estuary sediment transport capacity.

\subsection{Historic scenarios}

Long-term tidal observations and bed level data for the lower Ems River are not available with sufficient accuracy and spatial resolution to setup historic scenarios at given time intervals. Therefore an alternative approach was followed, using anecdotal information on straightening of river bends and channel deepening (Table 1), and long-term high and low water observations (Fig. 3).

Continuous tidal elevation data near the entrance of the lower Ems River is not available before 2001 (only HW and LW observations), and therefore, historic model scenarios cannot be forced with actual water level observations. Because of this lack of data, but also to be able to compare the different model scenarios, all historic scenarios are forced with the identical boundary conditions from the year 2005. Since high and low waters vary with the 18.6 year nodal cycle, the 2005 hydrodynamic conditions are representative for (approximately) 1945, 1965 and 1985, as well. Therefore, the historic bed levels scenarios are chosen to correspond to these nodal variations.

The observed bed level in 2005 (Fig. 2) is used as a reference bathymetry and adapted using anecdotal information
(Table 1) on changes in the navigational depth. The relation between navigational depth and bed level is related to a tidal level (MHW or CD, see Table 1), which varies along the river and in time, requiring the use of water level observations (Fig. 3) to convert historic MHW/CD levels to absolute vertical coordinates. Figure 2 shows the resulting model thalweg depths for 1945, 1965, 1985 and 2005.

Using the 2005 hydrodynamic and sediment transport model settings and boundaries (described in previous sections), combined with the bathymetric scenarios of Fig. 2, the model is calibrated against high and low water observations by changing the bed roughness within the same range as for the 2005 calibration ( $n=0.01)$; typical for mud-dominated systems to $n=0.02$ (typical for sand-dominated systems). Around 1945, a bed roughness of $n=0.02$ best reproduces the observations (Fig. 10), especially for the high water levels. From 1945 onwards the required bed roughness progressively decreases in time - both 1965 and 1985 water levels can be approximated with a Manning roughness value of $n=0.015$. These results have two important implications. First, the change in effective bed roughness corresponds to anecdotal information on the change from a sand-dominated system to a fluid-mud dominated system (i.e. Krebs and Weilbeer 2008). Secondly, the observed tidal amplification is caused by deepening but also by a decrease in bed roughness, with both effects probably being equally important.

The sediment transport model setup for 2005 is subsequently applied to the calibrated hydrodynamic scenarios for the different years. The sediment concentration computed in the lower Ems River is several orders of magnitude lower in the years 1945-1985 compared to 2005 throughout the lower Ems River (see Pogum and Leerort in Fig. 11). The difference 
Fig. 10 Observed and computed HW and LW at Pogum (top panel), Leerort (second panel), and Papenburg (lower panel). HW (LW) is defined as the yearly average of every high water (low water) per tidal cycle

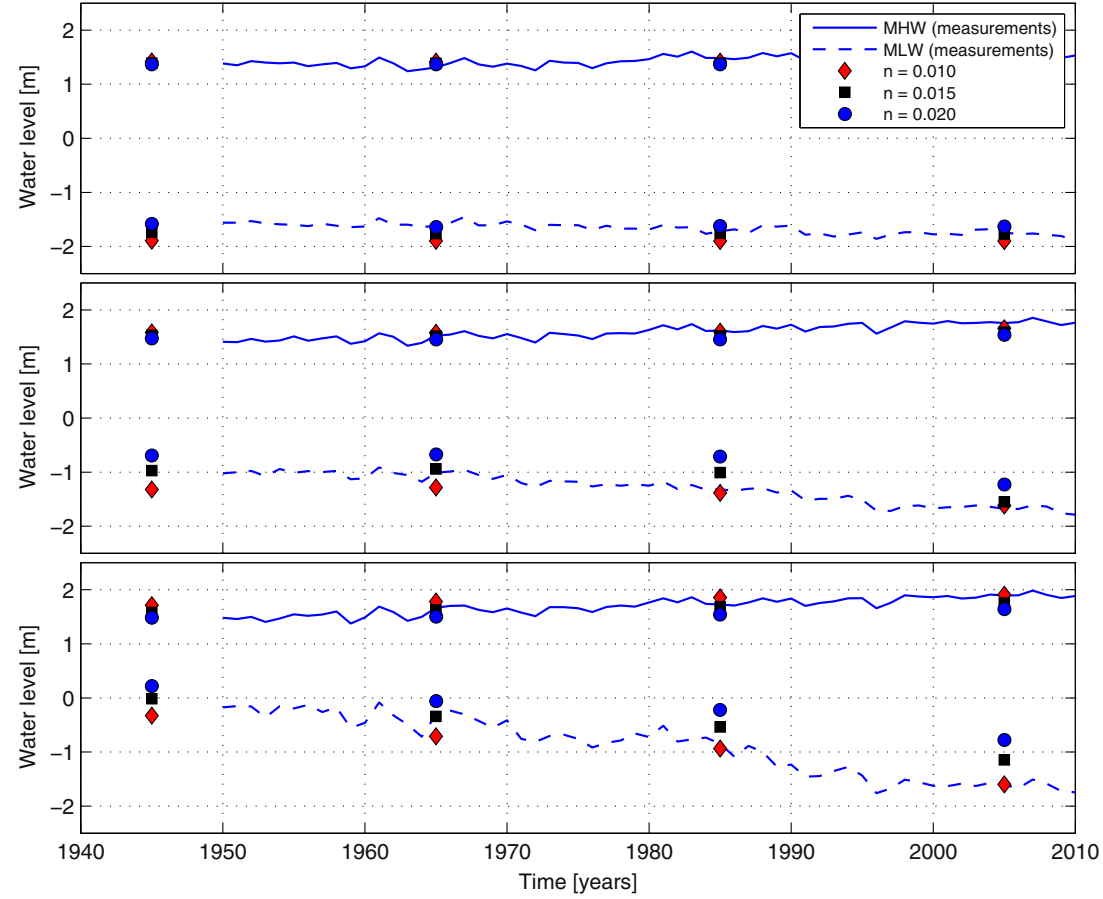

between these simulations is the bed level (Fig. 2) and the bed roughness (as calibrated using water levels, see Fig. 10). The model therefore suggests that the sediment concentration strongly increased between 1985 and 2005, which is supported by observations: Schuttelaars et al. (2013) report a 3 to 4 -fold increase of the sediment concentration in the lower Ems River from 1975 to 2005 . Although their observations in 2005 reflect near-surface conditions and the SSC peaks at only
Fig. 11 Observed discharge at Versen in 2005 (top panel), computed sediment concentration at Pogum (middle panel), and Leerort (bottom panel), for 1945 (green), 1965 (blue), 1985 (red), and 2005 (grey), with variable roughness $(n=0.020,0.015$, 0.015 and 0.010 , respectively) based on the hydrodynamic calibration (Fig. 10). Suspended sediment concentration observations (2005) are in black. The 1985 model results are very similar to 1965 , and therefore, largely hidden

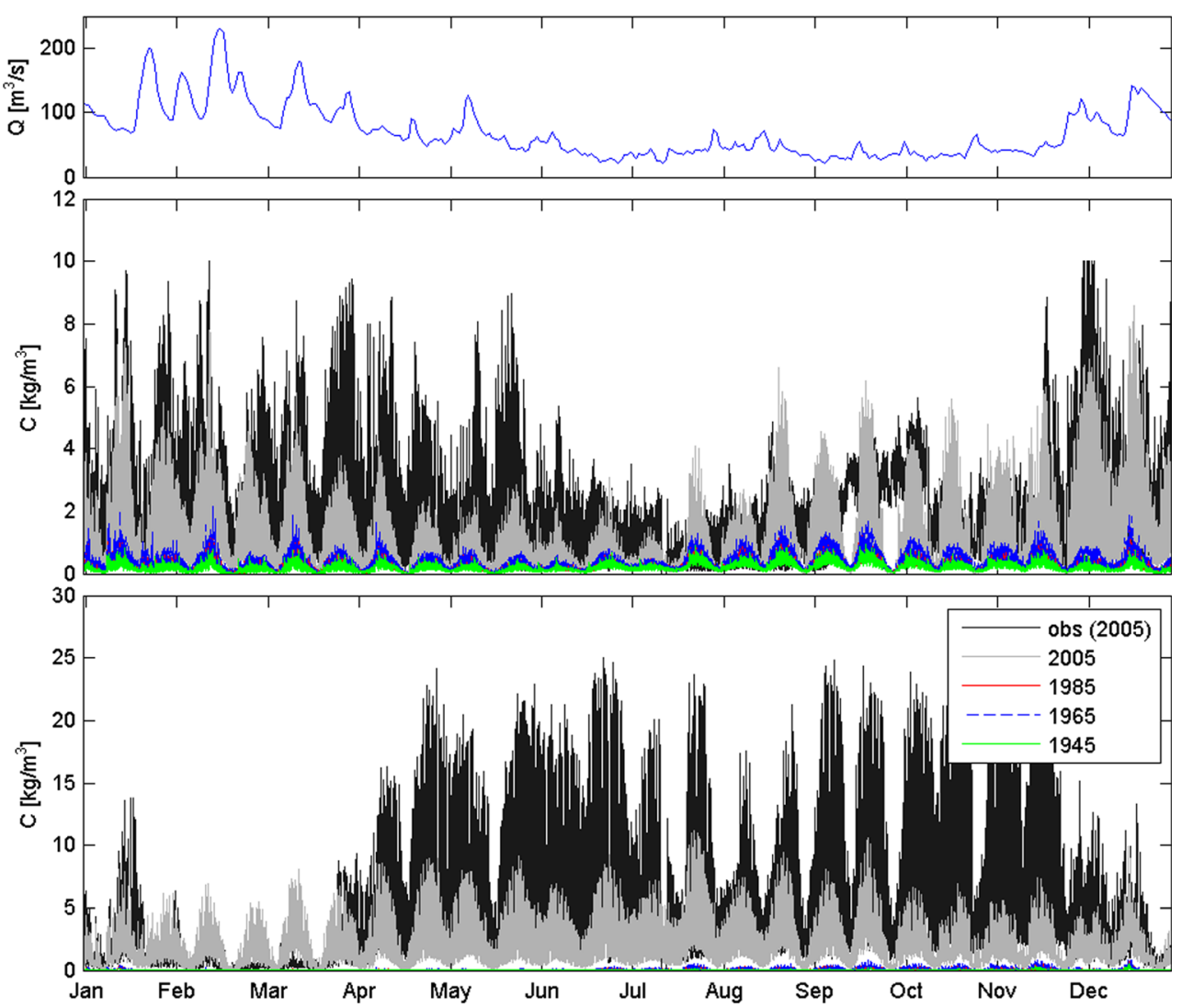


$1 \mathrm{~kg} / \mathrm{m}^{3}$, the trend suggests that the model captures at least some of the mechanisms governing this transition. These mechanisms are therefore analysed in more detail in the following section.

\section{Sediment transport mechanisms}

Sediment is transported into the lower Ems River, and subsequently re-distributed by a combination of estuarine circulation, tidal asymmetry, internal asymmetry, flocculation asymmetry (Winterwerp 2011), sediment-induced density-driven flows (Talke et al. 2009) and settling lag effects (Chernetsky et al. 2010). Sediment is probably flushed out of the lower Ems River by river discharge (Postma 1981; Spingat and Oumeraci 2000; de Jonge et al. 2014). The relative importance of tidal asymmetry and river discharge can be quantified in detail with the numerical model developed here. Therefore, we will first analyse the 2005 model runs to quantify the present-day sediment transport mechanisms, and subsequently evaluate historic model scenarios to understand which mechanisms were critical to the observed increase in suspended sediment concentration in the lower Ems River. The analysis of transport processes focuses on transport processes in the channel (even though transport directions on the intertidal flats may be opposite to transport in the channel; e.g. Ralston et al. 2012) for two reasons. First, sediment transport is dominated by erosion and formation of fluid mud which is located in the deeper part of the channel. Second, the intertidal area is about three times smaller than the subtidal area (Herrling and Niemeyer 2008). Combined with the much smaller average water depth, the total transport over the flats is much lower than transport in the channel.

\subsection{Present-day sediment transport mechanisms}

Any asymmetry in the hydrodynamics (spatially or temporally) will generate residual transport of fine sediment, as long as the sediment particles have a finite settling velocity and critical shear stress for erosion (van Maren and Winterwerp 2013). An asymmetry in flow velocity can be induced by residual flow and by tidal asymmetry. Tidal asymmetry is a persistent difference in ebb and flood without a residual component, which can manifest itself in different maximum flow velocities (and consequently different durations of ebb and flood) but can also have the form of a difference in slack tide duration (with equal ebb and flood velocities).

In the lower Ems River, the main source of tidal asymmetry is the interaction of $\mathrm{M}_{2}$ with its principal overtide $\mathrm{M}_{4}$ (Fig. 4), and consequently, this type of tidal asymmetry is determined by the phase lag in the velocity of these two constituents: $\theta_{u}=2 \phi_{u_{M 2}}-\phi_{u_{M 4}}$. For $\theta_{u}=-90$ to $90^{\circ}$, the peak flood flow velocity is larger than the peak ebb flow velocity (with maximum asymmetry at $\left.\theta_{u}=0^{\circ}\right)$; see, e.g. Friedrichs and Aubrey (1988). Since fine sediment transport typically scales with $u^{3}$ to $u^{4}$ (e.g. Winterwerp 2001) larger peak flood flow velocities lead to landward transport. For $\theta_{u}=0$ to $180^{\circ}$, the duration of HW slack is longer than that of LW slack. Sediment transported landward during flood therefore has a longer period to settle at slack tide, than sediment transported seaward during ebb, resulting in net landward transport. The computed velocity phase differences $\theta_{u}$ decrease from $\sim 100^{\circ}$ (Knock) to $\sim 0^{\circ}$ (Papenburg) for all model scenarios, very much in line with the observations by Chernetsky et al. (2010), see Fig. 12d.

The type of asymmetry can also be related to the phase lag in the water levels (for which usually a larger amount and more accurate data is available): $\theta_{\zeta}=2 \phi_{\xi_{M 2}}-\phi_{S_{M 4}}$. The relation between the type of asymmetry (determined by $\theta_{u}$ ) and $\theta_{\zeta}$ then primarily depends on the phase difference between water levels and flow velocity $\phi_{\xi_{M 2}}-\phi_{u_{M 2}}$. In the Ems, this phase difference is typically $65^{\circ}$ to $75^{\circ}$ (Fig. 12e). For such a phase difference, HW slack tide dominates from $\theta_{\zeta}=70$ to $250^{\circ}$ (maximum at $\theta_{\zeta}=160^{\circ}$ ) and flood flow asymmetry tide dominates from $\theta_{\zeta}=$ -20 to $160^{\circ}$ (maximum at $\theta_{\zeta}=70^{\circ}$ ). The computed water level phase differences $\theta_{\zeta}$ decrease from $\sim 170^{\circ}$ (Knock) to $\sim 90^{\circ}$ (Papenburg), supported by the observational data. Therefore, the tides evolve from HW slack tide dominant at the entrance (Pogum) to flood-dominant up-estuary (Papenburg). This pattern is supported by the SSC observations and model results in Figs. 8 and 9: at Pogum and Terborg the LW slack tide period is so short that the flood concentration peak immediately follows the ebb concentration peak, and little or no sediment settles. The HW slack period is much longer, and sediment transported up-estuary has time to settle on the bed. Such a mechanism effectively transports sediment up-estuary (Dronkers 1986). Further upstream (Leerort and Papenburg) the sediment concentration becomes more asymmetric, with higher sediment concentrations during the flood than during the ebb, characteristic for tides with a peak flood flow asymmetry (Fig. 8).

A measure for the degree of asymmetry is $a_{\zeta_{M 4}} / a_{\zeta_{M 2}}$, the water level amplitude ratio of $\mathrm{M}_{2}$ and $\mathrm{M}_{4}$, which increases in up-estuary direction. Even though the model reproduces $a_{\zeta_{M 2}}$ reasonably (Fig. 12a), the increase in $a_{\zeta_{M 4}} / a_{\zeta_{M 2}}$ (and therefore, $a_{\zeta_{M 4}}$ ) upstream of Terborg is overestimated (Fig. 12b, as already indicated by Fig. 4). So even though the transition from HW slack tide to flood-dominant tides (determined by $\theta$ ) is well captured, the model overestimates the degree of the flood-dominant tidal asymmetry.

The mechanism balancing this up-estuary sediment transport (by slack tide asymmetry and peak flow asymmetry) is provided by the down-estuary transport resulting from the river discharge (Spingat and Oumeraci 2000). This is evaluated with the computed bed shear stress $\tau_{b}$ as a function of river discharge $Q$ (Fig. 13). At Pogum and Terborg, the average of the bed shear stresses is close to zero and independent of $Q$. Apparently, the river discharge has negligible effect on the bed 
Fig. 12 a Water level amplitude of $\mathrm{M}_{2} a_{\zeta_{M 2}}$ in $1945,1965,1985$ and 2005. b Amplitude ratio of $\mathrm{M}_{4}$ to $\mathrm{M}_{2} a_{\zeta_{M 4}} / a_{\zeta_{M 2}}$. c Phase difference between $\mathrm{M}_{2}$ and $\mathrm{M}_{4}$ for water levels $\left(2 \phi_{\xi_{M 2}}-\phi_{\varsigma_{M 4}}\right)$. d Phase difference between $\mathrm{M}_{2}$ and $\mathrm{M}_{4}$ for depth-averaged flow velocity $2 \phi_{u_{M 2}}-\phi_{u_{M 4}}$. e Phase difference between water levels and depth-averaged flow velocity $\phi_{\xi_{M 2}}-\phi_{u_{M 2}}$. The blue dots are observations from 2005 presented in this paper (water levels) or from Chernetsky et al. (2010; flow velocities). The red diamonds are observations in 1980 from Chernetsky et al. (2010)

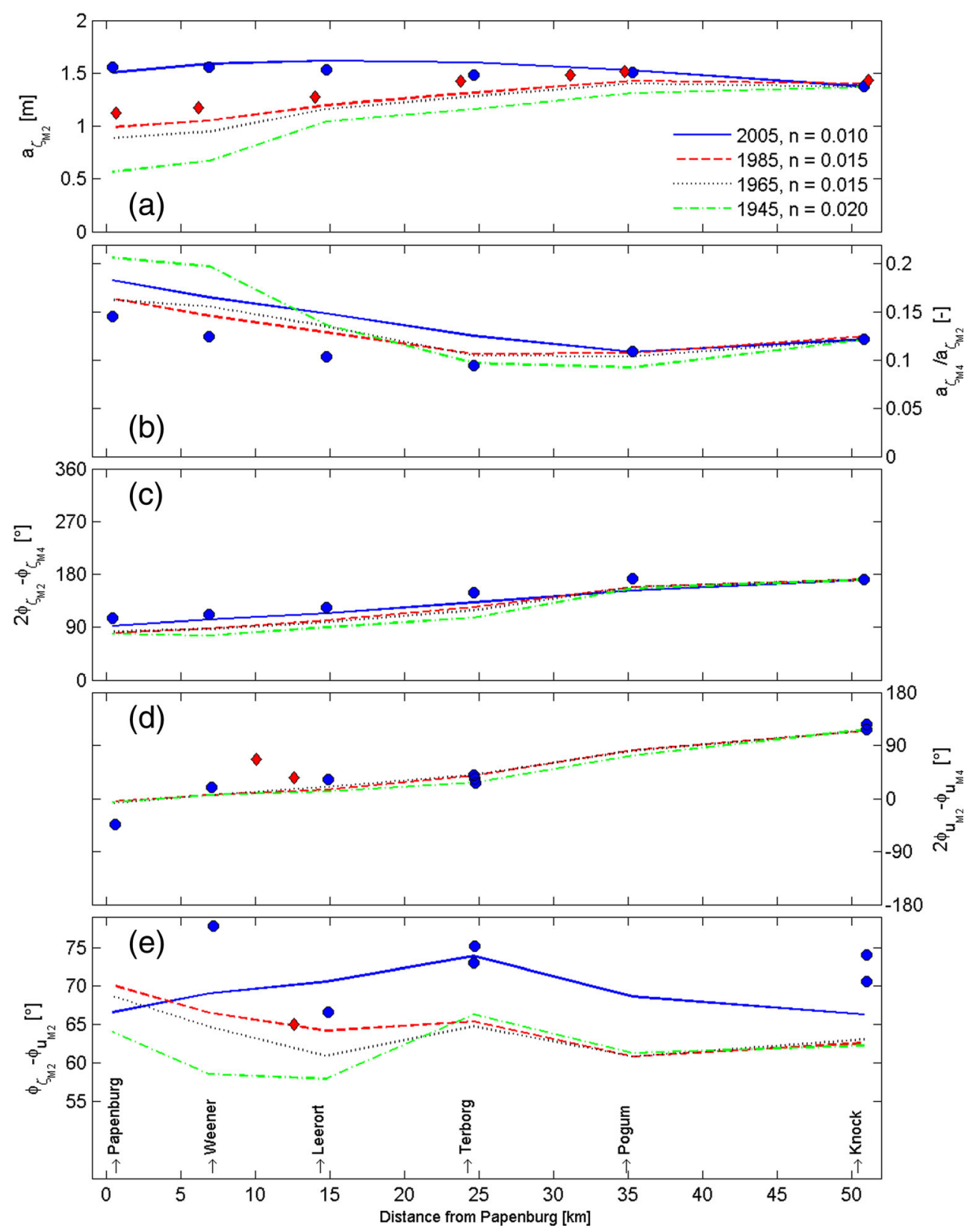

shear stress at these stations. The average of the computed bed shear stresses is in ebb direction for the more up-estuary stations Weener and Papenburg, due to the long period of low bed shear stress during the ebb. However, this ebb-dominance becomes less pronounced or is reversed when a critical shear stress for erosion $\tau_{c r}$ is introduced $\left(\tau_{b}-\tau_{c r}\right)$ because of the skewness of the computed bed shear stress distribution. Using only $\tau_{b}$, values exceeding $\tau_{c r}$ (conditions at which erosion of the bed is expected), leads to a flood-directed average $\tau_{b}$ at Terborg and Weener. At Weener, $\tau_{b}-\tau_{c r}$ changes from flood-directed to ebb-directed at a discharge of $120 \mathrm{~m}^{3} / \mathrm{s}$ while the average is permanently ebb- directed at Papenburg.

Hence, only during fairly large river discharges, the modelled up-estuary sediment flux generated by tidal asymmetry is balanced by a river discharge generated downestuary flux. As a result, the modelled sediment concentration in the upper reaches of the estuary is largest during low discharge conditions (Leerort in Fig. 11) whereas the computed sediment concentration in the lower reaches of the estuary (Pogum in Fig. 11) is highest during high discharge conditions. In the next section, we will evaluate how fine sediment importing and exporting mechanism have changed in the past decades.

\subsection{Historic changes}

The numerical model predicts a sharp increase in suspended sediment concentrations after 1985, in line with observations 
Fig. 13 Computed bed shear stress $\tau_{b}$ as a function of river discharge at Versen in the channel thalweg at Pogum, Terborg, Weener and Papenburg. The black dots indicate bed shear stresses computed every half hour, the thick blue line the average bed shear stress (binned by discharge) and the thick dashed red line the average excess bed shear stress $\tau_{b}-\tau_{c r}$ (with $\tau_{c r}=0.5 \mathrm{~Pa}$ ). A positive $\tau_{b}$ reflects flood direction, a negative $\tau_{b}$ reflects ebb direction
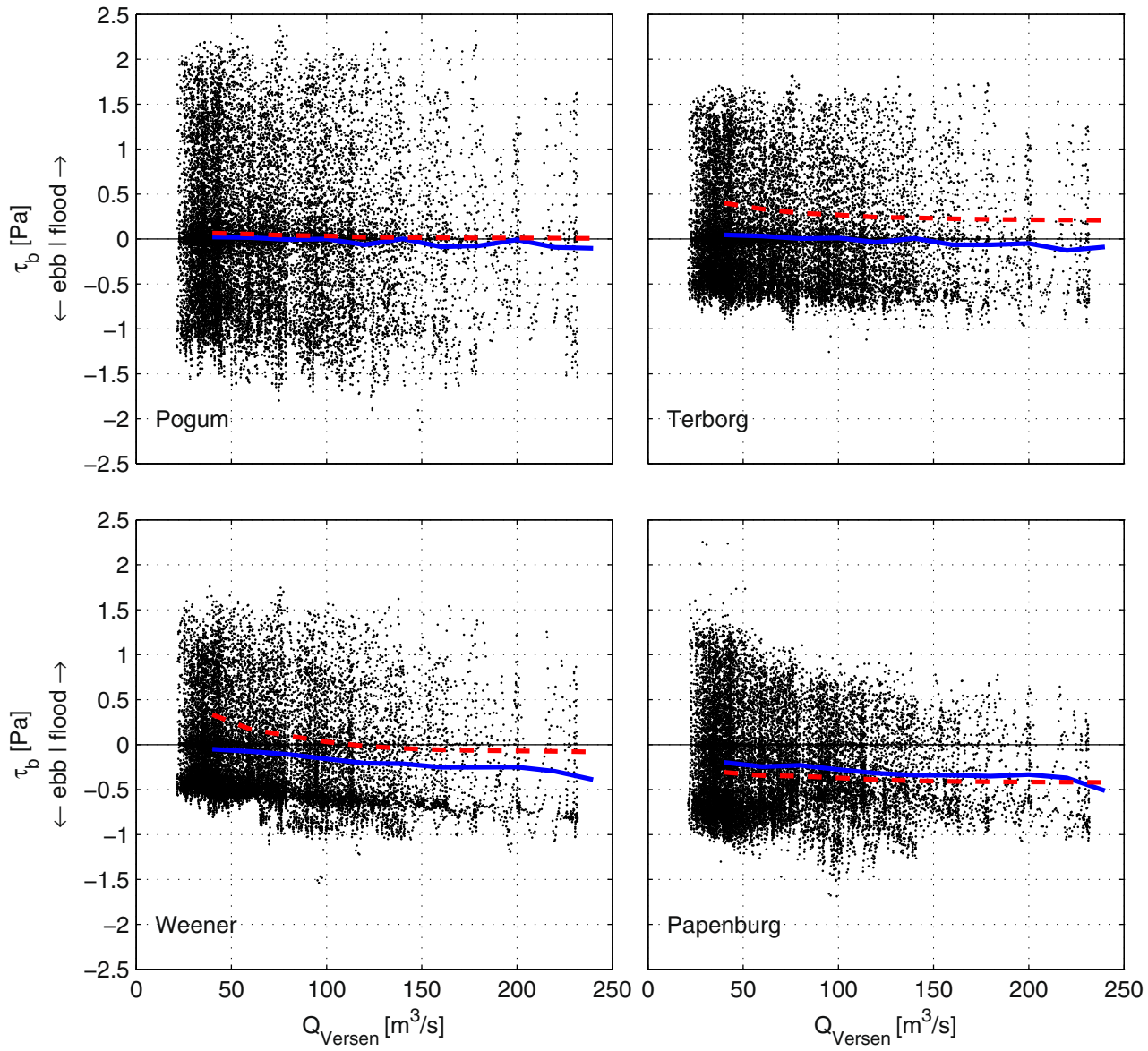

(Schuttelaars et al. 2013). Analysing the changes in sediment transport mechanisms (as discussed above) in time should reveal why the model computes this increase, and may provide a more quantitative insight in the mechanism that have led to the present highly turbid state of the lower Ems River.

Surprisingly, the computed asymmetry in $\theta_{\zeta}$ and $\theta_{u}$ changed little over time (Fig. 12). This is in line with the observations presented by Chernetsky et al. (2010) from 1980, also showing a minor change compared to 2005. All historic scenarios remain flood-dominant or HW slack dominant, both importing fine sediments. The computed degree of asymmetry $a_{\zeta_{M 4}} / a_{\zeta_{M 2}}$ is lower in 1965 and 1985, but larger in 1945. So even though the tides strongly amplified in the past decades (as in Fig. 3), the degree and type of tidal asymmetry remained fairly constant. Despite constant asymmetry parameters $a_{\zeta_{M 4}} / a_{\zeta_{M 2}}$ and $\theta$, the gross sediment transport rate did increase because the amplitudes of $\mathrm{M}_{2}$ and $\mathrm{M}_{4}$ increased over time. The existing difference between the total sediment flux transported during the flood and during the ebb (due to tidal asymmetry) therefore also became larger. As a result, the net up-estuary tidal transport has become larger in the past decades due to the increasing tidal amplitude.

An increasing import of sediment contributes to a larger suspended sediment concentration. However, a change in sediment exporting processes may be as effective. Due to deepening of the lower Ems River, its water depth increases. For a given river discharge $Q$ and a uniform cross-section, the flow velocity component generated by the river discharge $u_{\mathrm{r}}$ scales inversely linear with the water depth. As a result, $u_{\mathrm{r}}$ must have decreased in the past decades. In 2005, the contribution of the river discharge to the flow was much smaller than the tidal component, and as a result the bed shear stress $\tau_{b}$ was larger during the flood than during the ebb for all discharge conditions at all stations except for Papenburg (where the bed shear stress during ebb exceeds those during flood at larger discharge; see Fig. 13). The changing relation between the ebb-flood asymmetry in $\tau_{b}$ and river discharge $Q$ is illustrated for station Weener (Fig. 14). In 2005, the maximum bed shear stress was always larger during the flood, irrespective of the discharge. However, in 1965-1985, peaks in $\tau_{b}$ were larger during ebb (compared to flood) for river dischargers exceeding $120 \mathrm{~m}^{3} / \mathrm{s}$ in 1965-1985. However, the average of the bed shear stress $\tau_{b}$, but also the average of the excess bed shear stress $\tau_{b}-\tau_{c r}$, is persistently in ebb direction for all scenarios except 2005. This change is even more pronounced in 1945, when the peaks in $\tau_{b}$ revert to ebb dominance at a river discharges exceeding $\sim 70 \mathrm{~m}^{3} / \mathrm{s}$. 
Fig. 14 Computed bed shear stress $\tau_{b}$ in the channel thalweg at Weener as a function of discharge at Versen, in 2005 (Manning's $n=$ 0.01 ), in 1985 (Manning's $n=$ 0.015 ), in 1965 (Manning's $n=$ 0.015 ) and in 1945 (Manning's $n=0.02$ ). The black dots indicate bed shear stresses computed every half hour, the thick blue line is the average bed shear stress (binned by discharge) and the thick dashed red line is the average excess bed shear stress $\tau_{b}$ $-\tau_{c r}$ (with $\tau_{c r}=0.5 \mathrm{~Pa}$ ). A positive $\tau_{b}$ is in the flood direction, a negative $\tau_{b}$ is in the ebb direction
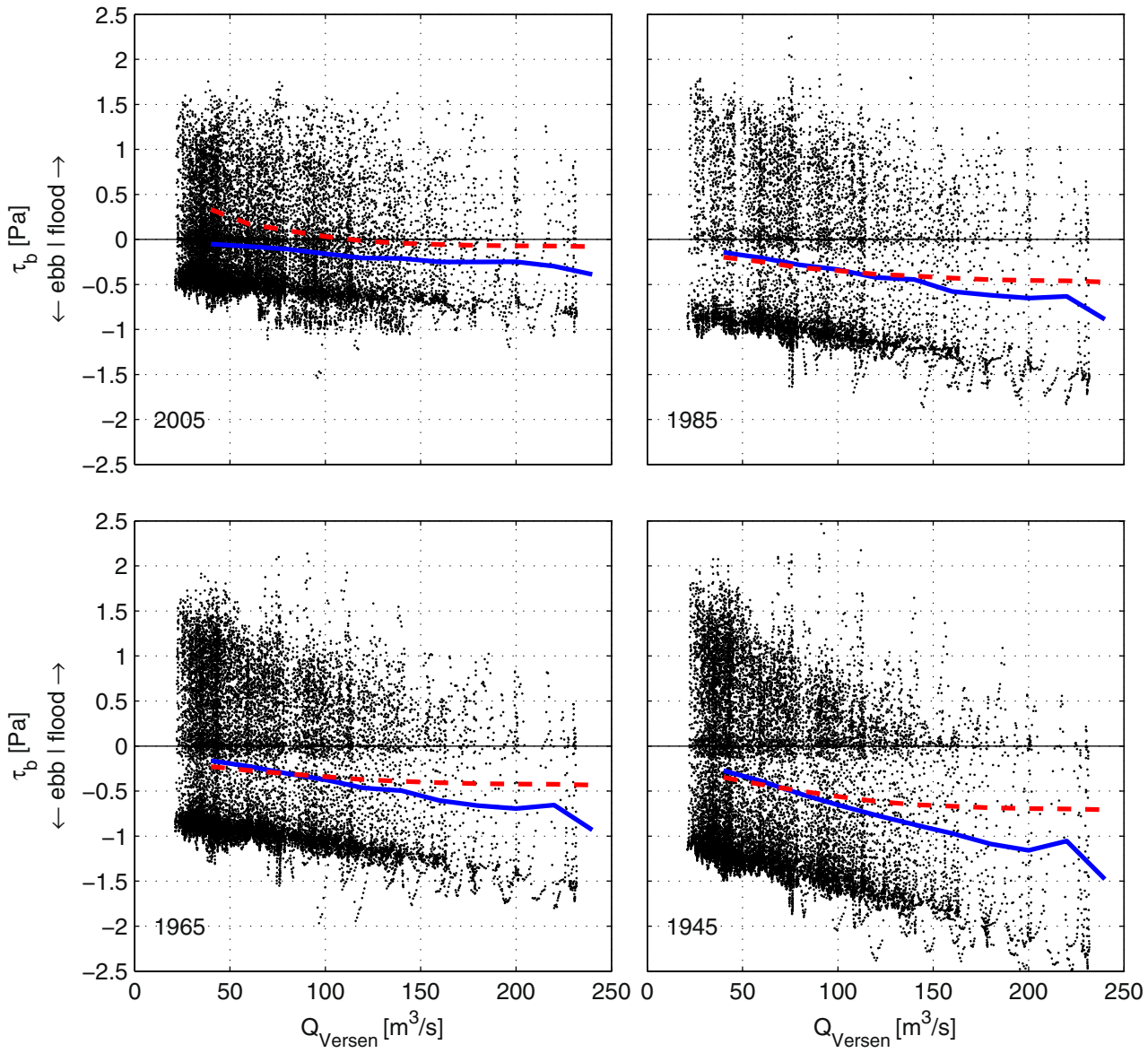

Apparently, the modelled increase in suspended sediment concentration (in 2005) results from a decrease in river flushing in addition to an increase in tide-induced up-estuary transport.

These historic scenarios differ in bathymetry, but also in hydraulic roughness. In order to distinguish their individual effect, the sediment concentrations are also computed for constant roughness values (using $n=0.01$ and $n=0.015$ for all historic years, see Fig. 15). A low bed roughness results in high sediment concentrations for all historic bathymetries. Apparently the tide-driven importing mechanisms become sufficiently strong to overcome the down-estuary transport generated by the river flow as long as the bed roughness is low. Note that this is an academic case: the hydrodynamics of these model runs are (except for 2005) in disagreement with water level observations. With moderate bed roughness (lower panel in Fig. 15), the sediment concentration is only high in 2005. These two observations have two important implications: (1) the 1990s deepening increased the up-estuary sediment import, which could then lead to a reduction in hydraulic drag, and (2) a return to the pre-1990 bed level will not lead to the pre-1990 water levels as long as the effective bed roughness remains low. These topics will be further discussed in the "Positive feedback mechanisms"section.

\section{Discussion}

\subsection{Transport mechanisms}

In the previous section, we concluded that in our model, the type and degree of asymmetry of the tidal flow velocity and water level changed comparatively little. However, with the increasing amplitudes of the tidal currents in time, the gross ebb and flood transports become larger, and therefore, also the residual transport (being the difference between ebb and flood transport). Simultaneously, the river-induced flushing decreased in time. However, other processes may play a role as well, which are discussed below.

The ETM of the lower Ems River differs from many other estuaries by its up-estuary location, extending deep into the fresh water region. This was explained by Talke et al. (2009) by sediment-induced density currents, transporting sediment further up-estuary than salinity-induced residual circulation could do. A sediment-induced density coupling is included in our model, generating a feedback mechanism between sediment concentration gradients, turbulence and hydrodynamics (e.g. Winterwerp 2001). Switching off the sediment-induced density coupling, however, (not shown) does not significantly modify the results. This suggests that in our model the 
Fig. 15 Computed sediment concentration at Leerort in 1965 (blue dashed), 1985 (red) and 2005 ( gray), using $n=0.01$ (top panel) and 0.015 (bottom panel)
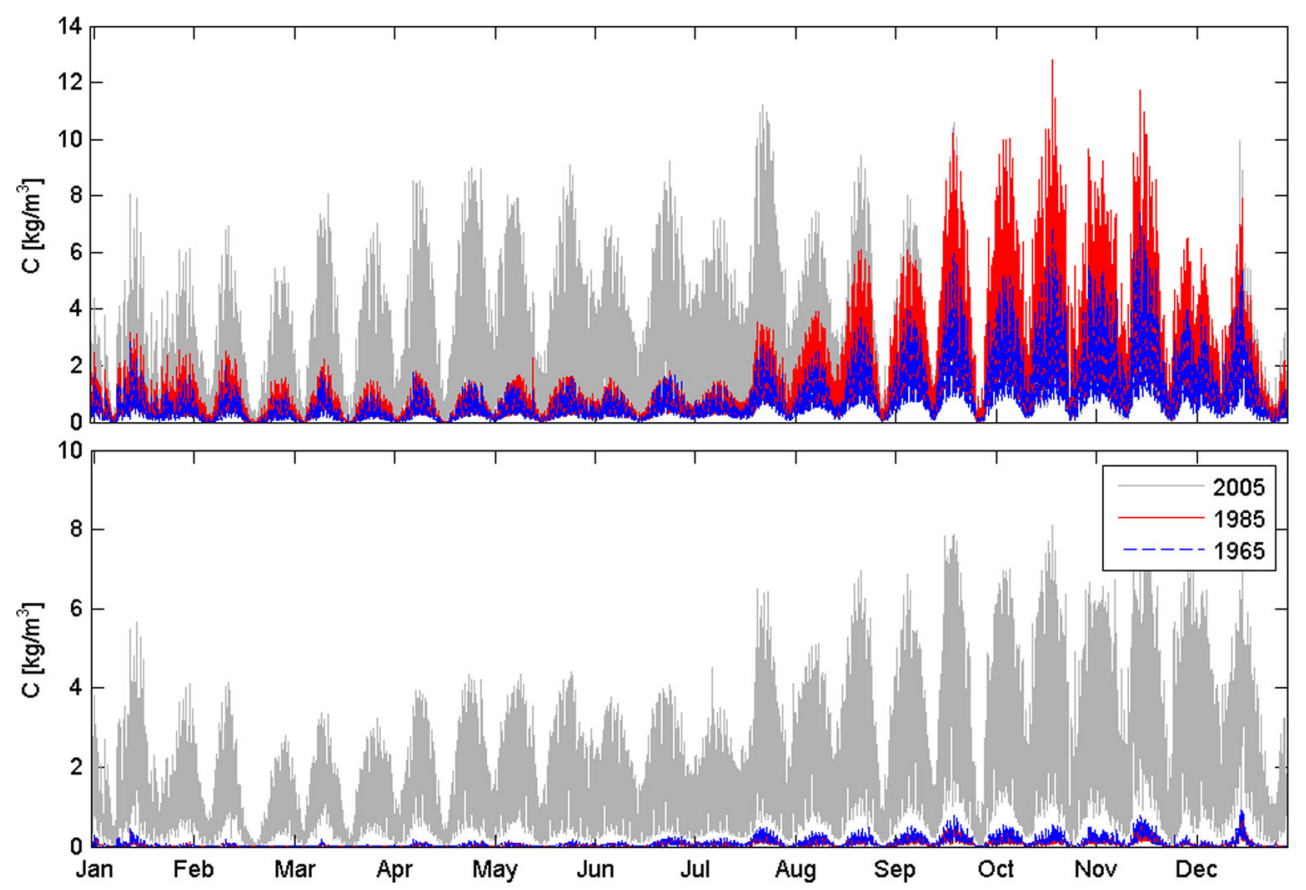

sediment-induced density currents are not responsible for the high suspended sediment concentration. Salinity-induced gravitational circulation is negligible up-estuary of Pogum, and therefore, also does not explain the high suspended sediment concentration after 1985.

Tidal asymmetry in mixing (Jay and Musiak 1994; Scully and Friedrichs 2003) and flocculation were postulated by Winterwerp (2011) to be important for up-estuary sediment transport. Tidal mixing asymmetry leads to stronger mixing during one phase of the tide, resulting in relatively more transport near-surface (where the flow velocity is largest). The vertical distribution of the suspended sediment concentration in our model can be inferred from Fig. 8, but especially Fig. 9, revealing that there is little difference in vertical mixing between ebb and flood. Therefore, vertical mixing asymmetry limitedly influences the modelled up-estuary transport. Flocculation asymmetry leads to faster settling flocs during one tidal phase compared to the other, and may therefore lead to residual transport. Flocculation was not implemented in our model, and therefore, did not contribute to the increase in SSC after 1985. Although mixing and flocculation asymmetry may play a role in the upstream transport in the lower Ems River, these could not contribute to our modelled transition from a normal estuary to a very turbid estuary.

\subsection{Hydraulic drag}

The hydraulic drag is a user-defined parameter to calibrate the modelled water levels to observations. The evolution of the effective hydraulic drag in time is in line with physical understanding, changing from a 'sand-bed' roughness to a 'mud- bed' roughness, and qualitatively corresponds to the friction parameters in the (semi) analytical models of Chernetsky et al. (2010), Winterwerp and Wang (2013) and de Jonge et al. (2014) as well as with the observed transition from a sandy bed to a muddy bed (Krebs and Weilbeer 2008). The bed roughness depends on bed forms (which may have existed but now disappeared) and on the suspended sediment concentration. Vertical stratification by suspended sediment reduces the vertical exchange of turbulence through buoyancy destruction, reducing viscous dissipation (Vanoni 1946). The resulting modification of the vertical velocity profile leads to a reduction in the apparent hydraulic drag (Winterwerp et al. 2009).

The effect of suspended sediment on water density and buoyancy destruction is implemented in our model. Previous work showed that this term is essential to capture the suspended sediment dynamics in high-concentration environments (Winterwerp and van Kessel 2003; van Maren 2007; van Maren et al. 2009). However, in this study, the sedimentinduced density effects only limitedly influenced the hydrodynamics and sediment dynamics. This may be the result of the vertical resolution of the model. Large vertical gradients cannot be resolved with the 10 equidistant $\sigma$-layers used in our model and as a result, the model underestimates sedimentinduced density effects. This may be resolved in three ways.

The simplest solution is to increase the vertical resolution, especially close to the bed. This may require a vertical resolution as low as several $\mathrm{mm}$, and therefore a large number of grid cells - the resulting computational time of the model may become very long. A second option is to relate the bed roughness to suspended sediment concentration using expressions such as 
derived by Winterwerp et al. (2009). A third option is to strengthen the effect of sediment on hydrodynamics through a modified Prandtl-Schmidt number $\sigma_{\mathrm{t}}$. In the $k-\varepsilon$ model, the turbulent energy $k$ and the turbulent energy dissipation $\varepsilon$ determine the vertical eddy viscosity $v$ through $v=c_{\mu} k^{2} / \varepsilon$ (where $c_{\mu}$ is a constant equal to 0.09). However, $v$ determines the vertical mixing of momentum while sediment is vertically mixed by the transfer of mass, which is parameterised with the eddy diffusivity $\Gamma$. $\Gamma$ is related to $v$ through the turbulent Prandtl-Schmidt number $\sigma_{t}$, as $\Gamma=v / \sigma_{\mathrm{t}}$. A common assumption is that $\sigma_{\mathrm{t}}$ equals 0.7 . However, Cellino and Graf (1999) observed in laboratory experiments that this value may be valid for clear water flows, but not for flows near sediment saturation. In that case, $\sigma_{t}$ should be closer to 2 . In a model with comparable vertical resolution as applied here, the observed sediment-induced stratification effects during hyperconcentrated floods could only be reproduced using a Prandtl-Schmidt number of 2 (van Maren et al. 2009).

Accounting for any of these three options may lead to a fully coupled feedback between tidal dynamics, the sediment concentration, and the bed roughness (as in Fig. 1). This may be explored as part of future research.

\subsection{Positive feedback mechanisms}

The model results suggest that only the deepening (phase 1 in Fig. 1) in the 1990s (part of the 2005 model bathymetry) sufficiently influences hydrodynamics (phase 2) to import large quantities of fine sediment (phase 3, see Fig. 11). As prescribed in the model, such an increasing import leads to reduced hydraulic roughness (phase 4). A reduced hydraulic roughness then further enhances the tidal amplification (phase 2, see Fig. 10) which again strengthens sediment import and raises the sediment concentration (phase 3: see Fig. 15). Analysis of the model results in the previous sections suggests that the net sediment import increased by tidal amplification and by reduced riverinduced flushing. Such reduced flushing is primarily influenced by geometry, rather than by hydraulic drag. Therefore, this mechanism does not contribute to the positive feedback mechanism depicted in Fig. 1. However, reduced flushing does strongly contribute to the impact of the deepening itself, adding to the initial effect of deepening on tidal deformation.

The model results also suggest that for low roughness conditions, the suspended sediment concentration in the lower Ems River is always high (independent of the geometry). This would suggest that a reduction to a bed level before the 1990 deepening, would only lead to reduced import and hence sediment concentration if all fine-grained sediment (which reduces the hydraulic roughness) is removed from the system. Stopping maintenance dredging would lead to lower water depths (possibly similar to a bed level before the 1990s), but since the deposited sediment would be primarily mud, the hydraulic drag remains low and the sediment import and sediment concentrations large. Therefore, the equilibrium water depth for these conditions is probably smaller than the sandy equilibrium water depth before channel deepening. Unless large amounts of sand are transported into the estuary (naturally or anthropogenic), the lower Ems River has transformed into an alternative, hyper-turbid state, which is very stable and self-maintaining (confirming Winterwerp et al. 2013).

\section{Conclusions}

A numerical model was setup, in which water levels and flow velocities were extensively calibrated against data. The calibration parameter in the hydrodynamic model is the bed roughness. In line with expectations, the effective bed roughness is decreasing from a typical sand-bed value in the 1940 s to a very low present-day value typical for smooth bed conditions. A morphodynamic model was setup which, despite its simplicity compared to the complex sedimentary conditions, reproduces some of the essential sediment dynamics. This model was applied to the historic hydrodynamic scenarios without further calibration, predicting a strong increase in suspended sediment concentration after 1985, in agreement with previously published observations.

Our model results suggest that the transition from a low-turbid to hyper-turbid estuary is the result of tidal amplification (despite constant phase lag differences or the relative strength of overtides) and decreasing riverine flushing. Further model analysis revealed that this transition may have already occurred for 'sand-bed' hydraulic drag conditions, which is critical for a subsequent rapid increase in turbidity and associated reduction in hydraulic drag. The following reduction in hydraulic drag further increased the sediment import capacity of the system, and hence the sediment concentration. The effect of hydraulic roughness is so large that a return to a pre-dredging depth is insufficient to significantly reduce sediment import and hence suspended sediment levels in the estuary. This means that not only the bed level needs to be raised; also the large quantities of mud need to be removed in order to restore the system to its pre-dredging conditions.

Acknowledgments This work is part of the project 'Mud dynamics in the Ems-Dollard', funded by the Dutch Ministry of Public Works in fulfilments of the requirements for the Water Framework Directives. Writing of this manuscript was supported by the Waddenacademie. We gratefully acknowledge the Niedersächsische Landesbetrieb für Wasserwirtschaft, Küsten- und Naturschutz and the Dutch ministry of public works for the use of their data. Suggestions by Carl Friedrichs and an anonymous reviewer greatly improved the manuscript.

Open Access This article is distributed under the terms of the Creative Commons Attribution License which permits any use, distribution, and reproduction in any medium, provided the original author(s) and the source are credited. 


\section{References}

Cellino M, Graf WH (1999) Sediment-laden flow in open-channels under noncapacity and capacity conditions. J Hydraul Eng 125(5):456562

Chernetsky AS, Schuttelaars HM, Talke SA (2010) The effect of tidal asymmetry and temporal settling lag on sediment trapping in tidal estuaries. Ocean Dyn 60:1219-1241

Chow VT (1959) Open channel hydraulics. McGraw-Hill, New York, $680 \mathrm{p}$

de Jonge VN, Schuttelaars HM, van Beusekom JEE, Talke SA, de Swart HE (2014) The influence of channel deepening on estuarine turbidity levels and dynamics, as exemplified by the Ems estuary. Estuar Coast Shelf Sci. doi:10.1016/j.ecss.2013.12.030

Donker JJA, de Swart HE (2013) Effects of bottom slope, flocculation and hindered settling on the coupled dynamics of currents and suspended sediment in highly turbid estuaries, a simple model. Ocean Dyn 63:311-327. doi:10.1007/s10236-013-0593-5

Dronkers JA (1986) Tide-induced residual transport of fine sediments. In: Van de Kreeke J (ed) Physics of shallow estuaries and bays. Springer, Berlin, pp 228-244

Friedrichs CT, Aubrey DG (1988) Non-linear tidal distortion in shallow well-mixed estuaries: a synthesis. Estuar Coast Shelf Sci 27:521545

Herrling G, Niemeyer HD (2008) Comparison of the hydrodynamic regime of 1937 and 2005 in the Ems estuary by applying mathematical modeling. Harbasins report, $30 \mathrm{p}$.

Jay DA, Musiak JD (1994) Particle trapping in estuarine tidal flows. J Geophys Res 99:445-461

Kerner M (2007) Effects of deepening the Elbe Estuary on sediment regime and water quality. Estuar Coast Shelf Sci 75:492-500

Krebs M, Weilbeer H (2008) Ems-dollart estuary. Die Küste 74:252-262

Lesser GR, Roelvink JA, van Kester JATM, Stelling GS (2004) Development and validation of a three-dimensional morphological model. Coast Eng 51:883-915

Papenmeier S, Schrottke K, Bartholoma A, Flemming BW (2013) Sedimentological and rheological properties of the water-solid bed interface in the Weser and Ems estuaries, North Sea, Germany: implications for fluid mud classification. Journal of Coastal Research. doi:10.2112/JCOASTRES-D-11-00144.1

Pawlowicz R, Beardsley B, Lentz S (2002) Classical tidal harmonic analysis including error estimates in MATLAB using T_TIDE. Comput Geosci 28:929-937

Postma H (1981) Exchange of materials between the North Sea and the Wadden Sea. Mar Geol 40:199-215

Ralston DK, Geyer WR, Warner JC (2012) Bathymetric controls on sediment transport in the Hudson River estuary: lateral asymmetry and frontal trapping. J Geophys Res 117:10013. doi:10.1029/2012JC008124

Richardson JF, Zaki WN (1954) Sedimentation and fluidization, part I. Trans Inst Chem Eng 32:35-53

Sanford LP, Halka JP (1993) Assessing the paradigm of mutually exclusive erosion and deposition of mud, with examples from upper Chesapeake Bay. Mar Geol 114:37-57

Schoemans M (2013) Tidal changes in the Lower Ems (1945-2005): reconstructing the effects of channel deepening and bottom roughness. BSc report, Utrecht University

Schrottke K, Becker M, Bartholomä A, Flemming BW, Hebbeln D (2006) Fluid mud dynamics in the Weser estuary turbidity zone tracked by high-resolution side-scan sonar and parametric subbottom profiler. Geo-Mar Lett 26:185-198
Schuttelaars HM, de Jonge VN, Chernetsky A (2013) Improving the predictive power when modelling physical effects of human interventions in estuarine systems. Ocean Coast Manag. doi:10.1016/j. ocecoaman.2012.05.009

Scully ME, Friedrichs CT (2003) The influence of asymmetries in overlying stratification on near-bed turbulence and sediment suspension in a partially mixed estuary. Ocean Dyn 53:208-219

Spingat F, Oumeraci H (2000) Schwebstoffdynamik in der Trubungszone des Ems-Astuars. Die Kuste 62:159-219

Talke SA, de Swart HE, Schuttelaars HM (2009) Feedback between residual circulations and sediment distribution in highly turbid estuaries: an analytical model. Cont Shelf Res 29:119-135. doi:10.1016/ j.csr.2007.09.002

Uncles RJ, Stephens JA, Smith RE (2002) The dependence of estuarine turbidity on tidal intrusion length, tidal range and residence time. Cont Shelf Res 22:1835-1856

Van Leussen W, Cornelisse J (1996) The determination of the sizes and settling velocities of estuarine flocs by an underwater video system. Neth J Sea Res 31:231-241

van Maren DS (2007) Grain size and sediment concentration effects on channel patterns of silt-laden rivers. Sediment Geol 202:297-316

Van Maren DS, Winterwerp JC (2013) The role of flow asymmetry and mud properties on tidal flat sedimentation. Cont Shelf Res 60S:S71S84

van Maren DS, Winterwerp JC, Wu BS, Zhou JJ (2009) Modelling hyperconcentrated flow in the Yellow River. Earth Surf Process Landf 34(4):596-612

Van Veen J (1950) Ebb and flood channel systems in the Netherlands tidal waters. J R Dutch Geogr Soc 67:303-325 (in Dutch)

Vanoni VA (1946) Transportation of suspended sediment by water. Trans Am Soc Civ Eng 111:67-133

Walther R, Schaguene J, Hamm L, David E (2012) Coupled 3D modeling of turbidity maximum dynamics in the Loire estuary, France. Coastal Engineering Proceedings, 1(33):11. http://dx.doi.org/10. 9753/icce.v33.sediment.22

Wang L (2010) Tide driven dynamics of subaqueous fluid mud layers in turbidity maximum zones of German estuaries. $\mathrm{PhD}$ thesis Bremen University, $96 \mathrm{p}$

Weilbeer H, Uliczka I (2012) Model studies for sediment management in the Outer Ems. BAW report Nr. A3955 03 10144, 61 p (in german)

Wilmott CJ (1981) On the validation of models. Phys Geogr 2:184-194

Winterwerp JC (2001) Stratification effects by cohesive and non-cohesive sediment. J Geophys Res 106(C10):22,559-22,574

Winterwerp JC (2007) On the deposition flux of cohesive sediment. In: Maa J, Sanford L, Schoelhamer D, Proceedings of the 8th International Conference on Nearshore and Estuarine Cohesive Sediment Transport Processes, INTERCOH-2003, Gloucester Point, USA, pp. 209-226

Winterwerp JC (2011) Fine sediment transport by tidal asymmetry in the high-concentrated Ems River: indications for a regime shift in response to channel deepening. Ocean Dyn 61:203-215

Winterwerp JC, van Kessel T (2003) Siltation by sediment-induced density currents. Ocean Dyn 53:186-196

Winterwerp JC, Wang ZB (2013) Man-induced regime shifts in small estuaries - I: theory. Ocean Dyn 63(11-12):1279-1292

Winterwerp JC, Lely M, He Q (2009) Sediment-induced buoyancy destruction and drag reduction in estuaries. Ocean Dyn 59:781-791

Winterwerp JC, Wang ZB, van Braeckel A, van Holland G, Kösters F (2013) Man-induced regime shifts in small estuaries - I: a comparison of rivers. Ocean Dyn 63(11-12):1293-1306 